\title{
Nitrogen dioxide decline and rebound observed by GOME-2 and TROPOMI during COVID-19 pandemic
}

\author{
Song Liu ${ }^{1,2} \cdot$ Pieter Valks $^{1} \cdot$ Steffen Beirle ${ }^{3}$. Diego G. Loyola ${ }^{1}$ \\ Received: 5 September 2020 / Accepted: 10 May 2021 / Published online: 28 August 2021 \\ (C) The Author(s) 2021
}

\begin{abstract}
Since its first confirmed case in December 2019, coronavirus disease 2019 (COVID-19) has become a worldwide pandemic with more than 90 million confirmed cases by January 2021. Countries around the world have enforced lockdown measures to prevent the spread of the virus, introducing a temporal change of air pollutants such as nitrogen dioxide $\left(\mathrm{NO}_{2}\right)$ that are strongly related to transportation, industry, and energy. In this study, $\mathrm{NO}_{2}$ variations over regions with strong responses to COVID-19 are analysed using datasets from the Global Ozone Monitoring Experiment-2 (GOME-2) sensor aboard the EUMETSAT Metop satellites and TROPOspheric Monitoring Instrument (TROPOMI) aboard the EU/ESA Sentinel-5 Precursor satellite. The global GOME-2 and TROPOMI NO 2 datasets are generated at the German Aerospace Center (DLR) using harmonized retrieval algorithms; potential influences of the long-term trend and seasonal cycle, as well as the shortterm meteorological variation, are taken into account statistically. We present the application of the GOME-2 data to analyze the lockdown-related $\mathrm{NO}_{2}$ variations for morning conditions. Consistent $\mathrm{NO}_{2}$ variations are observed for the GOME-2 measurements and the early afternoon TROPOMI data: regions with strong social responses to COVID-19 in Asia, Europe, North America, and South America show strong $\mathrm{NO}_{2}$ reductions of $\sim 30-50 \%$ on average due to restriction of social and economic activities, followed by a gradual rebound with lifted restriction measures.
\end{abstract}

Keywords COVID-19 · Tropospheric $\mathrm{NO}_{2}$ - GOME-2 $\cdot$ TROPOMI $\cdot$ Harmonized retrieval

\section{Introduction}

On 31 December 2019, an infectious pneumonia of unknown cause, subsequently named as coronavirus disease 2019 (COVID-19), was detected in Wuhan in China. The COVID19 outbreak was announced as a pandemic in mid-March 2020 and has caused more than 90 million confirmed cases and more than 1.5 million deaths around the world as of January 2021 (https://coronavirus.jhu.edu/map.html). In an effort to prevent the wide and rapid spread of the novel severe virus, countries have imposed national or local restrictions,

Song Liu

lius7@sustech.edu.cn

1 Deutsches Zentrum für Luft- und Raumfahrt (DLR), Institut für Methodik der Fernerkundung (IMF), Oberpfaffenhofen, Germany

2 Present address: School of Environmental Science and Engineering, Southern University of Science and Technology, Shenzhen, China

3 Max Planck Institute for Chemistry, Mainz, Germany such as ordering to stay at home, banning on public gathering, and closing non-essential shops and services.

The slowdown and recovery in social and economic activities around the world usually introduce a temporal change of air pollution, particularly for air pollutants strongly related to transportation, industry, and energy. Nitrogen dioxide $\left(\mathrm{NO}_{2}\right)$ is one of the most important and prominent air pollutants affecting human health and ecosystem. Large amounts of $\mathrm{NO}_{2}$ are produced anthropogenically in the boundary layer by industrial processes, power generation, transportation, and biomass burning over polluted hotspots. The relatively short atmospheric lifetime of $\mathrm{NO}_{2}$ (hours near the surface) facilitates establishing a direct link between observed tropospheric $\mathrm{NO}_{2}$ columns and emissions strengths (Richter 2009; Seinfeld and Pandis 2016).

A global and continuous monitoring of atmospheric $\mathrm{NO}_{2}$ abundances has been provided by European spaceborne instruments, such as Global Ozone Monitoring Experiment (GOME) aboard ERS-2 (Burrows et al. 1999), Scanning Imaging Absorption SpectroMeter for Atmospheric CHartographY (SCIAMACHY) aboard Envisat (Bovensmann et al. 1999), Ozone Monitoring Instrument (OMI) aboard 
EOS-Aura (Levelt et al. 2006), Global Ozone Monitoring Experiment-2 (GOME-2) aboard Metop (Callies et al. 2000; Munro et al. 2016), and TROPOspheric Monitoring Instrument (TROPOMI) aboard Sentinel-5 Precursor (Veefkind et al. 2012). The GOME-2 instruments have been providing global pictures of the atmospheric composition since 2007 and will extend this unique dataset until 2027. GOME-2 provides morning observations of $\mathrm{NO}_{2}$ at $\sim 09: 30$ local time, which complement early afternoon measurements from OMI or TROPOMI at $\sim 13: 30$ local time. The long-term GOME-2 measurements have been widely used in trend studies (Mijling et al. 2013; Hilboll et al. 2013; 2017), satellite dataset intercomparisons (Irie et al. 2012; Krotkov et al. 2017), and emission estimations (Gu et al. 2014; Miyazaki et al. 2017; Ding et al. 2017). The TROPOMI sensor, launched in 2017 with an unprecedented spatial resolution of $7 \mathrm{~km} \times 3.5 \mathrm{~km}(5.5 \mathrm{~km} \times 3.5 \mathrm{~km}$ after August 2019, van Geffen et al. (2020a)), allows local studies of distribution and evolution of $\mathrm{NO}_{2}$ (Stavrakou et al. 2020; Goldberg et al. 2020a; Georgoulias et al. 2020) and regional emission estimates (Lorente et al. 2019; Beirle et al. 2019; van der A et al. 2020; Huber et al. 2020).

The analysis of $\mathrm{NO}_{2}$ concentration variations, however, is not straightforward due to the strong dependency on meteorological conditions, such as solar irradiance and wind fields. Figures 1 and 2 present two examples of $\mathrm{NO}_{2}$ monthly variations (gray lines) measured by GOME-2 on MetOp-A for eastern China $\left(21^{\circ} \mathrm{N}-41^{\circ} \mathrm{N}, 110^{\circ} \mathrm{E}-122^{\circ} \mathrm{E}\right)$ and northern Italy $\left(45^{\circ} \mathrm{N}-46.5^{\circ} \mathrm{N}, 7^{\circ} \mathrm{E}-13^{\circ} \mathrm{E}\right)$ in $2007-$ 2019. The tropospheric $\mathrm{NO}_{2}$ columns are generally higher in winter due to the use of combustion power plants for heating and due to the fact that the lower solar irradiances increase the lifetime of $\mathrm{NO}_{2}$ in the atmosphere. In addition, the tropospheric $\mathrm{NO}_{2}$ columns change over short timescales (hours and days) depending on wind speeds and wind directions that interact with the physical features of the landscape to determine the movement and dispersal of air pollutants. Therefore, $\mathrm{NO}_{2}$ changes are typically analyzed using values averaged over long timeframes (months, seasons, and years) based on a long-term satellite dataset (Hilboll et al. 2013; Duncan et al. 2016; Georgoulias et al. 2019). To improve the robustness of the derived temporal changes, chemical transport models (Liu et al. 2020a; Koukouli et al. 2021) or comprehensive statistical models (Hayn et al. 2009; Zhou et al. 2012) can be additionally used.

Based on the spaceborne $\mathrm{NO}_{2}$ data from OMI and TROPOMI, recent works have reported the decrease of $\mathrm{NO}_{2}$ concentration during the COVID-19 pandemic lockdown across the world (Bauwens et al. 2020). For instance, decreases of tropospheric $\mathrm{NO}_{2}$ columns by up to $70 \%$ are observed for Chinese populated regions (Fan et al. 2020; Huang and Sun 2020) partly attributed to the decline in anthropogenic emissions related to the COVID-19 crisis (Ding et al. 2020; Zhang et al. 2020). Similar strong decreases by up to $60 \%$ are visible in regions with high population and heavy industry, such as India (Singh and Chauhan 2020), southern Europe (Chen et al. 2020; Baldasano 2020), the western USA (Liu et al. 2020b), and South America (Nakada and Urban 2020; Zalakeviciute et al. 2020). These studies generally calculate the weekly or monthly averages of $\mathrm{NO}_{2}$ data during the COVID-19 lockdown in 2020 and compare to the same timeframe within recent 5 years or to the period prior to the lockdown in 2020. In addition, the importance of the meteorological variations between years has been explored in regional studies for China (Liu et al. 2020a; Zhao et al. 2020) and the USA (Goldberg et al. 2020b), which can affect the $\mathrm{NO}_{2}$ variations by $15 \%$.

In this work, we present an analysis of the $\mathrm{NO}_{2}$ variations due to enacting and lifting restrictions on movements in response to the COVID-19 outbreak, covering the severely affected countries across the polluted continents. Long-term $\mathrm{NO}_{2}$ measurements from the satellite instrument GOME2 and high-resolution observations from TROPOMI are applied, with corrections for trend, season, and meteorology. Compared to previous studies, the synergy between morning and early afternoon satellite $\mathrm{NO}_{2}$ observations is explored. The GOME- 2 and TROPOMI measurements are retrieved in a consistent manner. The time series of morning $\mathrm{NO}_{2}$ columns derived from GOME-2 spans over $\sim 14$ years of observations.

In "Spaceborne $\mathrm{NO}_{2}$ measurements," the GOME-2 and TROPOMI instruments and the algorithm for tropospheric $\mathrm{NO}_{2}$ column retrieval are briefly introduced, followed by a description of the correction method. "COVID-19 impact on $\mathrm{NO}_{2}$ pollution" presents the $\mathrm{NO}_{2}$ variations observed before, during, and after the COVOD-19 lockdown for regions in Asia, Europe, North America, and South America dominated by anthropogenic emissions. The summary is given in "Conclusion".

\section{Spaceborne $\mathrm{NO}_{2}$ measurements}

\section{GOME-2}

GOME-2 is a nadir-scanning ultraviolet, visible, and nearinfrared spectrometer measuring the Earth's backscattered radiance and extra-terrestrial solar irradiance in the spectral range between 240 and $790 \mathrm{~nm}$. The first GOME-2 was launched in October 2006 aboard the EUMETSAT MetOpA satellite, and a second GOME-2 was launched in September 2012 aboard MetOp-B (throughout this study referred to as GOME-2A and GOME-2B, respectively). The consistent long-term dataset is further extended by the third 
GOME-2 on the MetOp-C platform launched in November 2018. The Sun-synchronous polar orbit has a daily equator crossing time of $\sim 9: 30$ local time. The default swath width of GOME-2 is $1920 \mathrm{~km}$, and the default ground pixel size is $80 \mathrm{~km} \times 40 \mathrm{~km}$ in the forward scan. A decreased swath of $960 \mathrm{~km}$ and an increased spatial resolution of $40 \mathrm{~km} \times 40$ $\mathrm{km}$ are employed by GOME-2A in a tandem operation of MetOp-A and MetOp-B from July 2013 onwards. See Munro et al. (2016) for more details on instrument design and performance.

The operational GOME-2 $\mathrm{NO}_{2}$ products are generated using the GOME Data Processor (GDP) algorithm (Valks et al. 2011) and provided by DLR in the framework of EUMETSAT's Satellite Application Facility on Atmospheric Composition Monitoring (AC SAF). Near-real-time, offline, and reprocessed GOME-2 level 2 and consolidated products are available via a dedicated FTP server and the EUMETSAT Data Centre (https://acsaf.org/). In the present study, the current operational product (Valks et al. 2020) is used.

\section{TROPOMI}

TROPOMI is a push broom imaging spectrometer covering wavelength bands between the ultraviolet and the shortwave infrared, launched in October 2017 aboard the EU/ESA Sentinel-5 Precursor satellite. TROPOMI provides $\mathrm{NO}_{2}$ observations with a spatial resolution of $5.5 \mathrm{~km} \times 3.5 \mathrm{~km}$ at nadir ( $7 \mathrm{~km} \times 3.5 \mathrm{~km}$ before August 2019). The swath width is $\sim 2600 \mathrm{~km}$ in the direction across the track of the satellite that allows daily global coverage. In combination with the morning observations from GOME-2, the early afternoon measurements $(\sim 13: 30$ local time) from TROPOMI allow a better study of $\mathrm{NO}_{2}$ diurnal variations. For further details, see Veefkind et al. (2012) and Kleipool et al. (2018).

The TROPOMI $\mathrm{NO}_{2}$ retrieval algorithm used in this study is developed at DLR and has been used to analyze the effect of traffic emission on air quality in Germany (https://atmos.eoc.dlr.de/sveld/). The retrieval is based on an improved algorithm originally designed for GOME-2 (Liu et al. 2019; Liu et al. 2020) and adapted for TROPOMI measurements with optimization related to the specific instrumental aspects. The TROPOMI $\mathrm{NO}_{2}$ dataset used in the study is available upon request.

\section{Tropospheric $\mathrm{NO}_{2}$ column retrieval}

The retrieval of tropospheric $\mathrm{NO}_{2}$ columns for the GOME2 and TROPOMI instruments follows a classical three-step scheme. First, the slant columns (namely the concentrations integrated along the effective light path from the Sun through the atmosphere to the instrument) are derived from the measured (ir)radiances using the differential optical absorption spectroscopy (DOAS) method (Platt and Stutz 2008). Second, the stratospheric contribution is estimated and separated from the slant columns using a modified reference sector method (Valks et al. 2011; Beirle et al. 2016), which uses the measurements over regions with negligible tropospheric $\mathrm{NO}_{2}$ abundance. The modified reference sector method requires no additional model input and can be considered as a complement to the stratospheric correction based on data assimilation, as implemented in the operational TROPOMI product (van Geffen et al. 2020a). Third, the tropospheric $\mathrm{NO}_{2}$ vertical columns are converted from the tropospheric slant columns by an air mass factor (AMF) calculation. The presence of clouds is taken into account using cloud parameters based on the Optical Cloud Recognition Algorithm (OCRA) and Retrieval Of Cloud Information using Neural Networks (ROCINN) algorithms (Lutz et al. 2016; Loyola et al. 2018) with the advantages of operational implementation and routine validation (Compernolle et al. 2020; Lambert et al. 2020). The satellite data are filtered for clouds (cloud radiance fraction $<0.5$ or cloud fraction $<\sim 0.3$ ) to reduce retrieval errors. The retrieved GOME-2 and TROPOMI measurements are aggregated based on an area-weighted tessellation to resolutions of $0.1^{\circ} \times 0.1^{\circ}$ and $0.025^{\circ} \times 0.025^{\circ}$, respectively.

Based on ground-based multi-axis differential optical absorption spectroscopy (MAX-DOAS) measurements, the GOME-2 validation results are generally within the target accuracy of $30 \%$ for suburban and remote conditions (Pinardi et al. 2014; Pinardi et al. 2017). Larger underestimations are observed for polluted urban situations, because the large GOME-2 pixel size $(80 \mathrm{~km} \times 40 \mathrm{~km} / 40$ $\mathrm{km} \times 40 \mathrm{~km}$ ) is less representative of the local urban $\mathrm{NO}_{2}$ pattern sampled by the ground-based instrument (Pinardi et al. 2020). With a pixel size more representative of the $\mathrm{NO}_{2}$ fields on local and regional scales, the retrieved TROPOMI measurements agree with MAX-DOAS data at the suburban Xianghe site in China (Hendrick et al. 2014) with a correlation coefficient of 0.96 and a mean bias of $-2.1 \times 10^{15} \mathrm{molec} / \mathrm{cm}^{2}$ or $-17.6 \%$ (Liu 2019, see Sect. 6.4 therein).

In comparison with the operational TROPOMI product (van Geffen et al. 2020a; van Geffen et al. 2020b), the retrieved TROPOMI tropospheric $\mathrm{NO}_{2}$ columns (Fig. S1) vary by $4 \times 10^{14}$ molec/cm ${ }^{2}$ on average (Fig. S2) due to the difference in the stratosphere-troposphere separation method. From Fig. S2, larger increases by more than $1 \times$ $10^{15} \mathrm{molec} / \mathrm{cm}^{2}$ are found mainly over polluted regions in winter as a result of the applications of different cloud parameters and different treatments of snow/ice scenarios in the AMF calculation (van der A et al. 2020). 
Fig. 1 Time series of monthly (gray line) and yearly (black dots) mean tropospheric $\mathrm{NO}_{2}$ columns measured by GOME-2A over eastern China $\left(21^{\circ} \mathrm{N}-41^{\circ} \mathrm{N}, 110^{\circ} \mathrm{E}-122^{\circ} \mathrm{E}\right)$. The linear fitting result for the yearly average shows a growth for 2007-2011 (red line) and a reduction for 2011-2019 (blue line). Slopes are 0.69 for 2007-2011 (red text) and -0.53 for 2011-2019 (blue text)

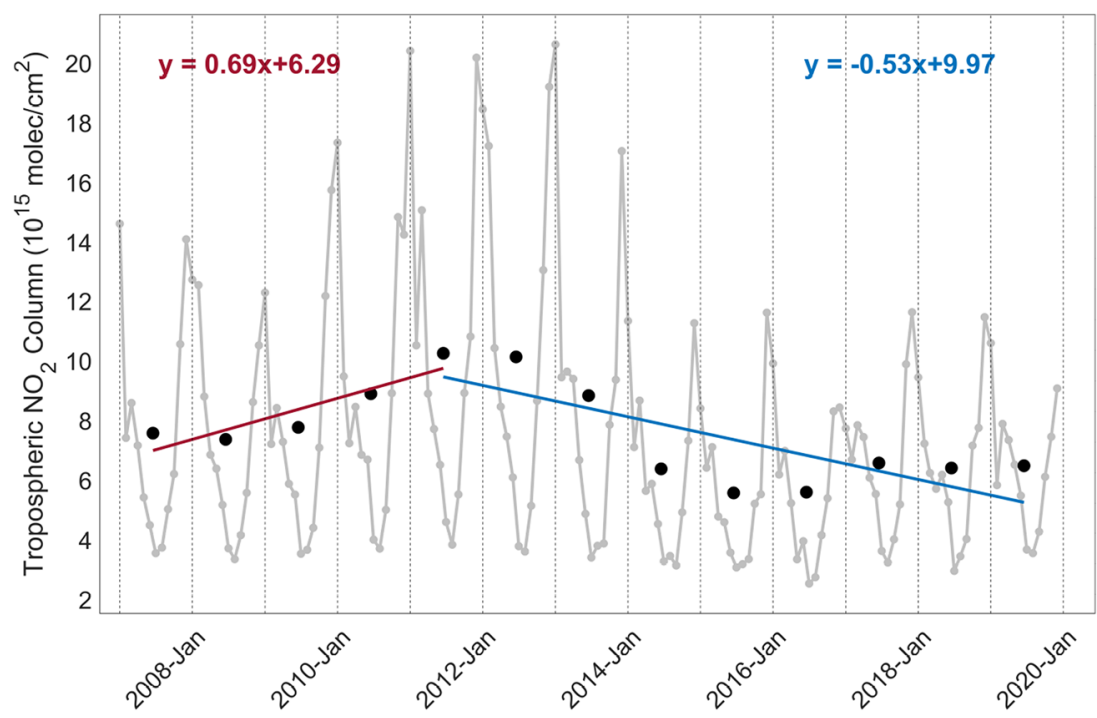

\section{Trend, seasonal, and meteorological corrections}

To consider the potential influences of long-term trends and seasonal cycles as well as short-term meteorological variations at a given location, the corrected tropospheric $\mathrm{NO}_{2}$ columns $V_{\text {corr }}$ are calculated for GOME-2 and TROPOMI with a statistical model:

$V_{\text {corr }}=\frac{V+m_{\text {trend }}\left(t_{y}, t_{m}\right)}{f_{\text {season }}\left(t_{m}\right) \times f_{\text {wind }}(u(t), v(t))}$.

For the observed time $t$ (year $t_{y}$, month $t_{m}$, and day $t_{d}$ ), the original tropospheric $\mathrm{NO}_{2}$ columns $V$ are adjusted with a trend correction term $m_{\text {trend }}$, a seasonal correction factor $f_{\text {season }}$, and a wind correction factor $f_{\text {wind }}$. The trend correction follows Bekbulat et al. (2020), who use the slope of historical data as the trend correction term for ground-based measurements and adjust the historical data to the 2020 reference. The seasonal correction and the wind correction apply the normalization method from Goldberg et al. (2020b), who modify the satellite observations to a reference with average seasonal and meteorological conditions.

The trend correction term $m_{\text {trend }}$ is calculated for GOME-2A and GOME-2B as the slope of the linear regression line (Bekbulat et al. 2020) based on GOME2A annual averages from 2007 to 2019. The assumption of linear trend has been widely used in previous works (Richter et al. 2005; Konovalov et al. 2010; Duncan et al. 2016; Georgoulias et al. 2019). To detect trend reversals in the $\sim 13$-year time series, a method suggested by Cermak et al. (2010) is used to find the year when a reversal from negative to positive trends or from positive to negative trends happens. Identified by minimizing a change point score, a trend reversal is reported if the trend for the period before or after the reversal year is statistically significant at the $95 \%$ confidence level and the long-term average tropospheric $\mathrm{NO}_{2}$ columns is larger than $1 \times 10^{15} \mathrm{molec} / \mathrm{cm}^{2}$ (Georgoulias et al. 2019). As shown in Fig. S3, extended regions over eastern China and parts of the North India Plain exhibit a reversal from positive to negative trends mostly in 2011 or 2012, in agreement with previous studies using satellite measurements or emission data (De Foy et al. 2016; van der A et al. 2017; Georgoulias et al. 2019). These reversals are partly explained by the implementation of clean technology (Bansal and Bandivadekar 2013; Liu et al. 2016), a stricter control of Chinese environmental regulations (CAAC 2013; Wu et al. 2017), and a slowdown in Indian economic development (Hilboll et al. 2017).

Figures 1 and 2 show the long-term trends of tropospheric $\mathrm{NO}_{2}$ columns measured by GOME-2A for eastern China $\left(21^{\circ} \mathrm{N}-41^{\circ} \mathrm{N}, 110^{\circ} \mathrm{E}-122^{\circ} \mathrm{E}\right)$ and northern Italy $\left(45^{\circ} \mathrm{N}-46.5^{\circ} \mathrm{N}, 7^{\circ} \mathrm{E}-13^{\circ} \mathrm{E}\right)$, including the slope and intercept of the linear regression analysis. For China, the annual trend correction is $0.69 \times 10^{15} \mathrm{molec} / \mathrm{cm}^{2}$ per year for $2007-2011$ and $-0.53 \times 10^{15} \mathrm{molec} / \mathrm{cm}^{2}$ per year for $2011-$ 2019 , indicating changes of $8.3 \% / y e a r$ and $-7.2 \% / y e a r$, respectively. The evaluations are confirmed by studies using OMI satellite measurements (Krotkov et al. 2016; Duncan et al. 2016; Georgoulias et al. 2020), who reported average changes of $8.4 \%$ /year before 2011 and $-7.0 \% / y e a r$ after 2011 for eastern China, and studies using emission data (Liu et al. 2016; van der A et al. 2017), who estimated an increase of $9.1 \%$ and a decrease of $6.5 \%$. For Italy, the annual trend correction is $-0.23 \times 10^{15} \mathrm{molec} / \mathrm{cm}^{2}$ per year, representing a reduction of $4.3 \%$ year of the tropospheric $\mathrm{NO}_{2}$ columns. Due to tightening vehicle emission standards (Euro 2007), a similar negative trend is detected by OMI (e.g., $-4.0 \% / y e a r$ from Duncan et al. (2016)) and emission data (e.g. -5.2\%/yr 
Fig. 2 Time series of monthly (gray line) and yearly (black dots) mean tropospheric $\mathrm{NO}_{2}$ columns measured by GOME-2A over northern Italy $\left(45^{\circ} \mathrm{N}-46.5^{\circ} \mathrm{N}, 7^{\circ} \mathrm{E}-13^{\circ} \mathrm{E}\right)$. The linear fitting result for the yearly average shows a decline (blue line) with a slope of -0.23

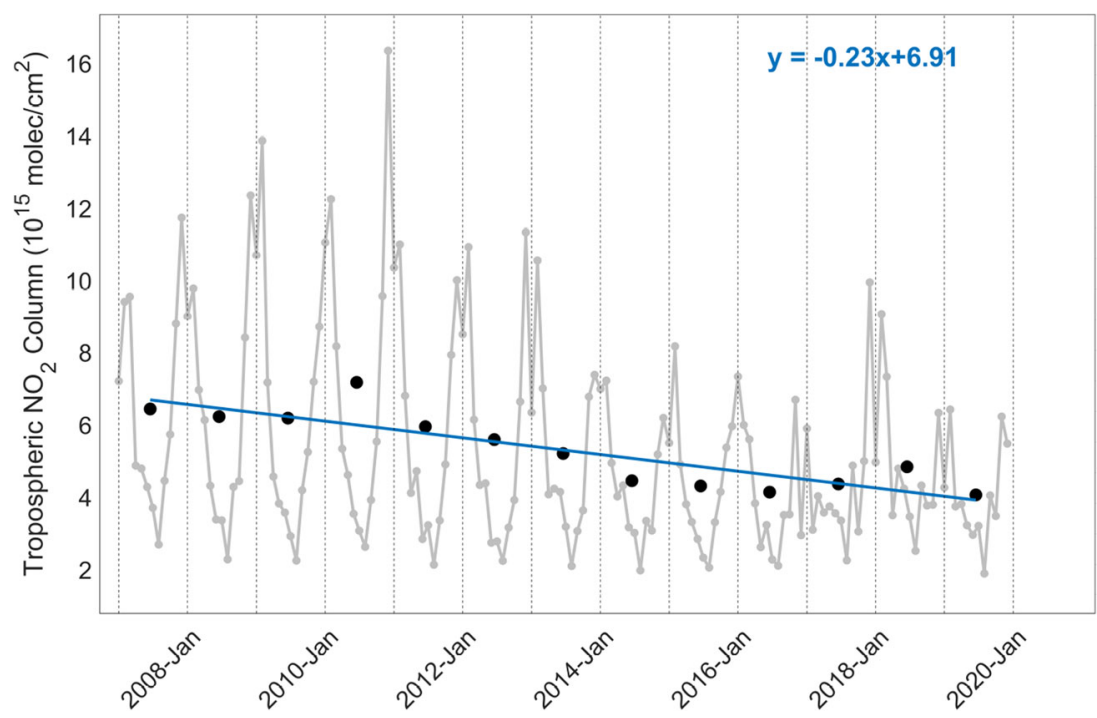

from Miyazaki et al. (2017)). Additional examples are gathered in Fig. S4 for large urban cities, where a negative trend is found for Los Angeles ( $-3.5 \% / y e a r)$ in the USA $\left(33.5^{\circ} \mathrm{N}-35.5^{\circ} \mathrm{N}, 117.25^{\circ} \mathrm{W}-119.25^{\circ} \mathrm{W}\right)$, and positive trends are observed for New Delhi (1.2\%/year) in India $\left(27.6^{\circ} \mathrm{N}-29.6^{\circ} \mathrm{N}, 76.2^{\circ} \mathrm{E}-78.2^{\circ} \mathrm{E}\right)$ and Lima $(2.8 \% / y e a r)$ in Peru $\left(11^{\circ} \mathrm{S}-13^{\circ} \mathrm{S}, 76^{\circ} \mathrm{W}-78^{\circ} \mathrm{W}\right)$.

The seasonal correction factor $f_{\text {season }}$ is calculated for GOME-2A, GOME-2B, and TROPOMI based on the climatological seasonal variability (the monthly averages divided by the annual average), derived using $\mathrm{NO}_{2}$ observations from 2007 to 2019 for GOME-2A, 2013 to 2019 for GOME-2B, and 2018 to 2019 for TROPOMI, respectively. From the GOME-2A time series examples in Figs. 1 and 2 and the multiple-year monthly mean data over Asia, Europe, and North America in Fig. S5, the tropospheric $\mathrm{NO}_{2}$ columns are largest in winter, and the seasonal correction factors are $\sim 3-4$ times higher in winter than in summer (Fig. S6), mainly due to the longer $\mathrm{NO}_{2}$ lifetime and higher emissions. As indicated by the EDGAR-HTAP_V2 emission data (https://edgar.jrc. ec.europa.eu/htap_v2/) in Fig. S7, the emissions from the residential sector, which is one of the main energy-related sources of $\mathrm{NO}_{2}$, increase for these northern mid-latitude regions in winter due to domestic heating.

The wind correction factor $f_{\text {wind }}$ is derived using the eastward and northward wind components $u$ and $v$, respectively, from the European Center for Medium range Weather Forecasting (ECMWF) ERA5 dataset (https://cds. climate.copernicus.eu/). The wind data at $10 \mathrm{~m}$ above the surface have a spatial resolution of $0.25^{\circ} \times 0.25^{\circ}$ and a temporal resolution of $6 \mathrm{~h}$. For different wind directions, wind speeds are averaged over $12 \mathrm{~h}$ prior to the satellite overpass time to approximately represent the effect of transport integrated over the lifetime of $\mathrm{NO}_{2}$ (Zhou et al.
2012). The $10 \mathrm{~m}$ data are representative of the wind fields within the lower boundary layer, particularly for regions with strong sources close to the surface (Hayn et al. 2009; Georgoulias et al. 2020). Influences of additional meteorological variables, such as precipitation, temperature, and solar irradiation, are partially considered by applying the corrections for season and wind (Zhou et al. 2012; Goldberg et al. 2020b). The cloud effects are not considered as the observations are filtered for clouds (see "Tropospheric $\mathrm{NO}_{2}$ column retrieval").

Figure 3 shows the wind influences on the tropospheric $\mathrm{NO}_{2}$ columns measured by TROPOMI in 2018-2019 for

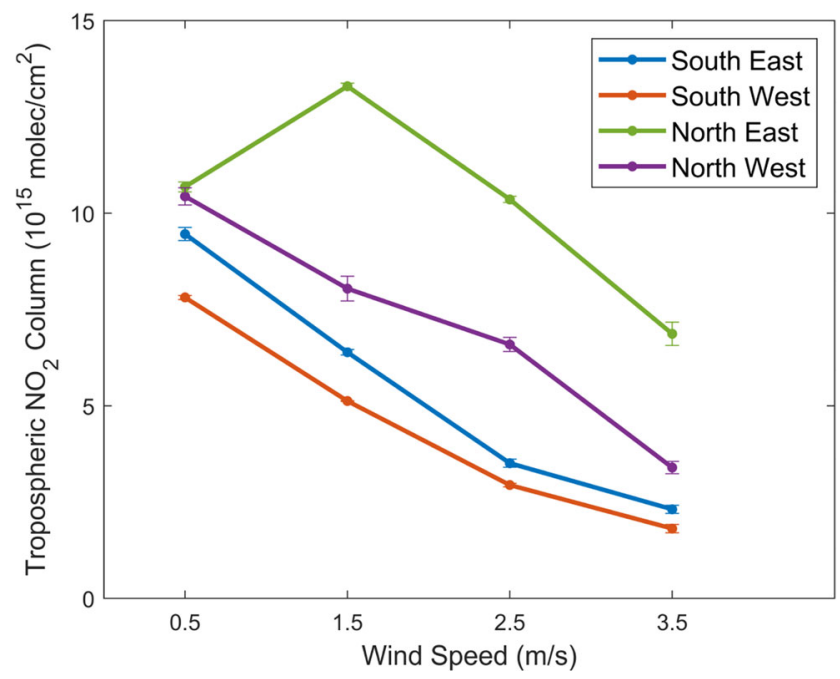

Fig. 3 Variations in TROPOMI tropospheric $\mathrm{NO}_{2}$ columns for 2018 2019 as a function of wind speed for different wind directions over Los Angeles in the southwestern USA $\left(34.0^{\circ} \mathrm{N}-34.25^{\circ} \mathrm{N}, 118.0^{\circ} \mathrm{W}-\right.$ $\left.118.25^{\circ} \mathrm{W}\right)$. The error bar shows the standard error of the mean. The average wind speed is $1.6 \mathrm{~m} / \mathrm{s}$. The average tropospheric $\mathrm{NO}_{2}$ column is $7.1 \times 10^{15} \mathrm{molec} / \mathrm{cm}^{2}$ 
Los Angeles located in the southwestern coast of the USA $\left(34.0^{\circ} \mathrm{N}-34.25^{\circ} \mathrm{N}, 118.0^{\circ} \mathrm{W}-118.25^{\circ} \mathrm{W}\right)$. The TROPOMI tropospheric $\mathrm{NO}_{2}$ columns decrease by $33-76 \%$ when the wind speed increases from 0.5 to $3.5 \mathrm{~m} / \mathrm{s}$ due to the faster dispersion away from the emission sources. For Los Angeles, the northeast wind (i.e., $\mathrm{u}<0$ and $\mathrm{v}<0$ ) yields the largest tropospheric $\mathrm{NO}_{2}$ columns with emission and transport from upwind, which can be $70 \%$ larger than the columns from other directions at the same wind speed, in agreement with estimations from the regional study from Goldberg et al. (2020b) using the operational TROPOMI data.

For each satellite pixel, $f_{\text {wind }}$ is implemented following the normalization method from Goldberg et al. (2020b). First, the ERA wind data with a $0.25^{\circ} \times 0.25^{\circ}$ resolution are bilinearly interpolated to $0.1^{\circ} \times 0.1^{\circ}$ for GOME- 2 and $0.025^{\circ} \times 0.025^{\circ}$ for TROPOMI. Second, wind climatologies are derived using the historical wind information and tropospheric $\mathrm{NO}_{2}$ columns (2007-2019 for GOME-2A, 2013-2019 for GOME-2B, and 2018-2019 for TROPOMI), indicating the $\mathrm{NO}_{2}$ dependencies on wind speed and wind direction. Third, based on the wind climatologies, correction values for each grid pixel are determined by normalizing to a reference that is set to have an average wind speed. Lastly, the correction values are modelled by the linear regression, based on which $f_{\text {wind }}$ is determined for the current ERA5 wind conditions.
Figure 4 shows the average wind directions and wind speeds in 16 March-15 April 2019 and the effect of applying the meteorological correction for TROPOMI tropospheric $\mathrm{NO}_{2}$ columns over the southwestern USA area. For Californian coastal cities with a mountainous terrain, such as Los Angeles and San Francisco, taking account of the meteorological condition (predominant west winds) affects the $\mathrm{NO}_{2}$ levels by up to $1 \times 10^{15} \mathrm{molec} / \mathrm{cm}^{2}(20 \%)$, mainly by reducing the $\mathrm{NO}_{2}$ underestimations for upwind regions and reducing the overestimations for downwind regions.

\section{COVID-19 impact on $\mathrm{NO}_{2}$ pollution}

\section{China}

China, where COVID-19 was first identified, was also the first country to impose the lockdown restrictions, starting from Wuhan and other cities in the Hubei region on 23 January 2020 to quarantine the center of COVID-19 outbreak. Similar measures have been imposed across China as of mid-March 2020. With the efforts mostly based on strict containment measures, the first epidemic wave has been under control by early April 2020, when the lockdowns ended or were largely relaxed.
Fig. 4 Average ERA5 wind directions and wind speeds as quiver plot and differences in tropospheric $\mathrm{NO}_{2}$ columns with and without the meteorological correction, as measured by TROPOMI over the southwestern USA in 16 March-15 April 2019

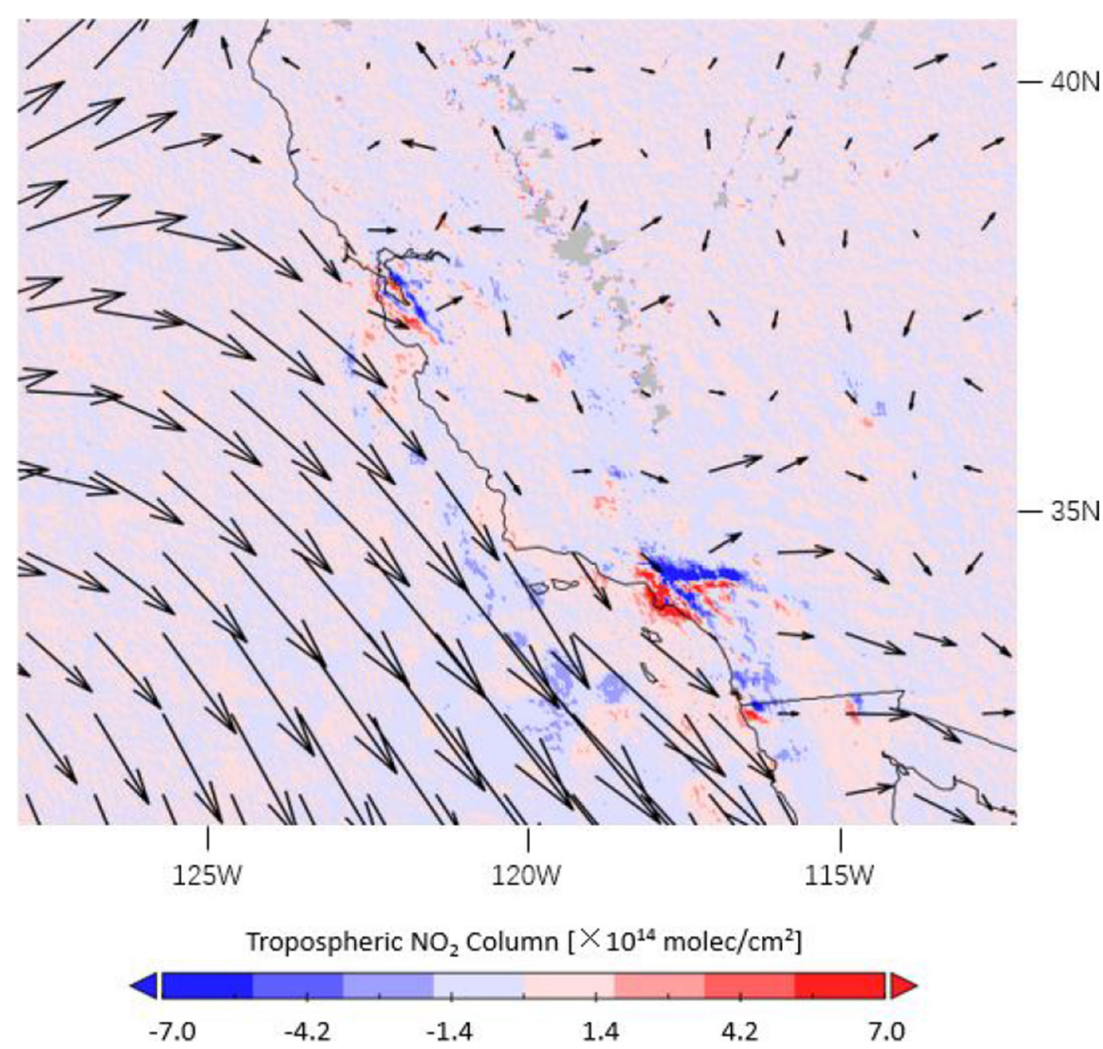




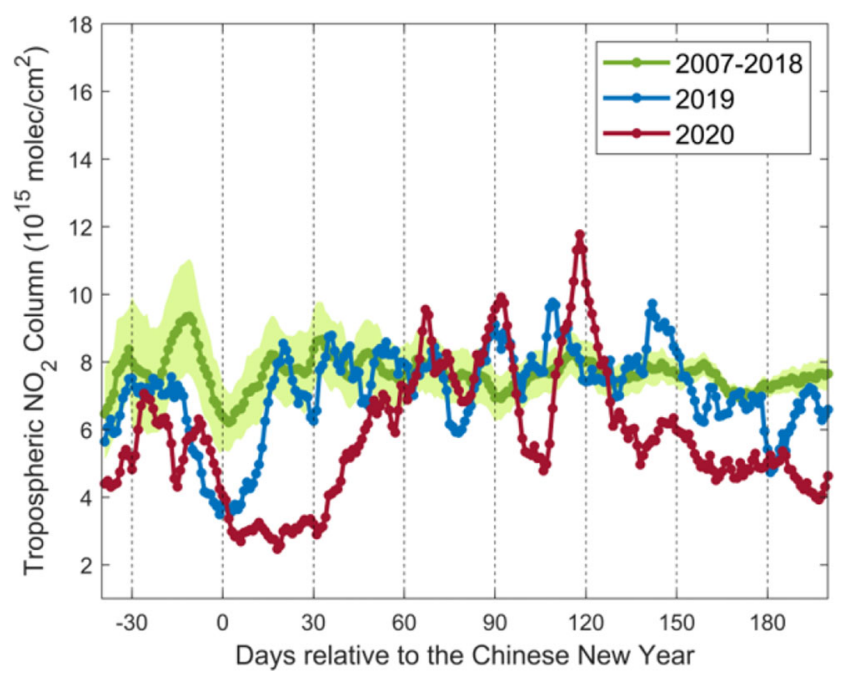

Fig. 5 Daily variations in 10-day moving averages of the corrected GOME-2A/B tropospheric $\mathrm{NO}_{2}$ columns over eastern China $\left(21^{\circ} \mathrm{N}-\right.$ $41^{\circ} \mathrm{N}, 110^{\circ} \mathrm{E}-122^{\circ} \mathrm{E}$ ) for $2007-2018$ (green), 2019 (blue), and 2020 (red). Green shading shows standard error of the mean for 2007-2018. The 2020 COVID-19 pandemic lockdown starts on 23 January. The 2020 Chinese New Year falls on 25 January. The yearly varying dates of the Chinese New Year are considered

Figure 5 shows the tropospheric $\mathrm{NO}_{2}$ daily variations in 10-day moving averages over eastern China $\left(21^{\circ} \mathrm{N}-\right.$ $41^{\circ} \mathrm{N}, 110^{\circ} \mathrm{E}-122^{\circ} \mathrm{E}$ ) for 2020 and historical data from
GOME-2A/B. Data are corrected for trend, season, and meteorology. In comparison with the uncorrected values in Fig. S8, the winter values in Fig. 5 are uniformly lower after accounting for the seasonal influence, and the summer values are higher. The meteorological correction affects the GOME-2 tropospheric $\mathrm{NO}_{2}$ columns by up to $8.5 \%$ during lockdown in Fig. S9. Smaller positive corrections factors in 2020 during lockdown indicate less favorable conditions for low $\mathrm{NO}_{2}$ as compared to 2019, in agreement with Liu et al. (2020a).

The analysis of the COVID-19 lockdown impact is complicated by the coincidence of the 7-day Chinese New Year holidays. Consistent with the historical data, the tropospheric $\mathrm{NO}_{2}$ columns in 2020 decrease by a factor of 2 before the New Year. The columns, however, do not increase back to the normal level after the holiday as the historical data mainly resulted from the lockdown measures, confirming previous findings using OMI data (Bauwens et al. 2020; Huang and Sun 2020). Due to the gradual recovery of social and economic activities, the columns start to rebound 1 month after the New Year (late February) and return to the normal level as previous years by early April with short-term variations partly related to observational errors. Higher $\mathrm{NO}_{2}$ levels are found during April and May 2020 due to the increased emissions from energy consumption and road transport (Zheng et al.
Fig. 6 Averages of the corrected tropospheric $\mathrm{NO}_{2}$ columns measured by TROPOMI over eastern China during lockdown in 23 January-22 March in 2020 and comparison with columns in the same time period in 2019
2019
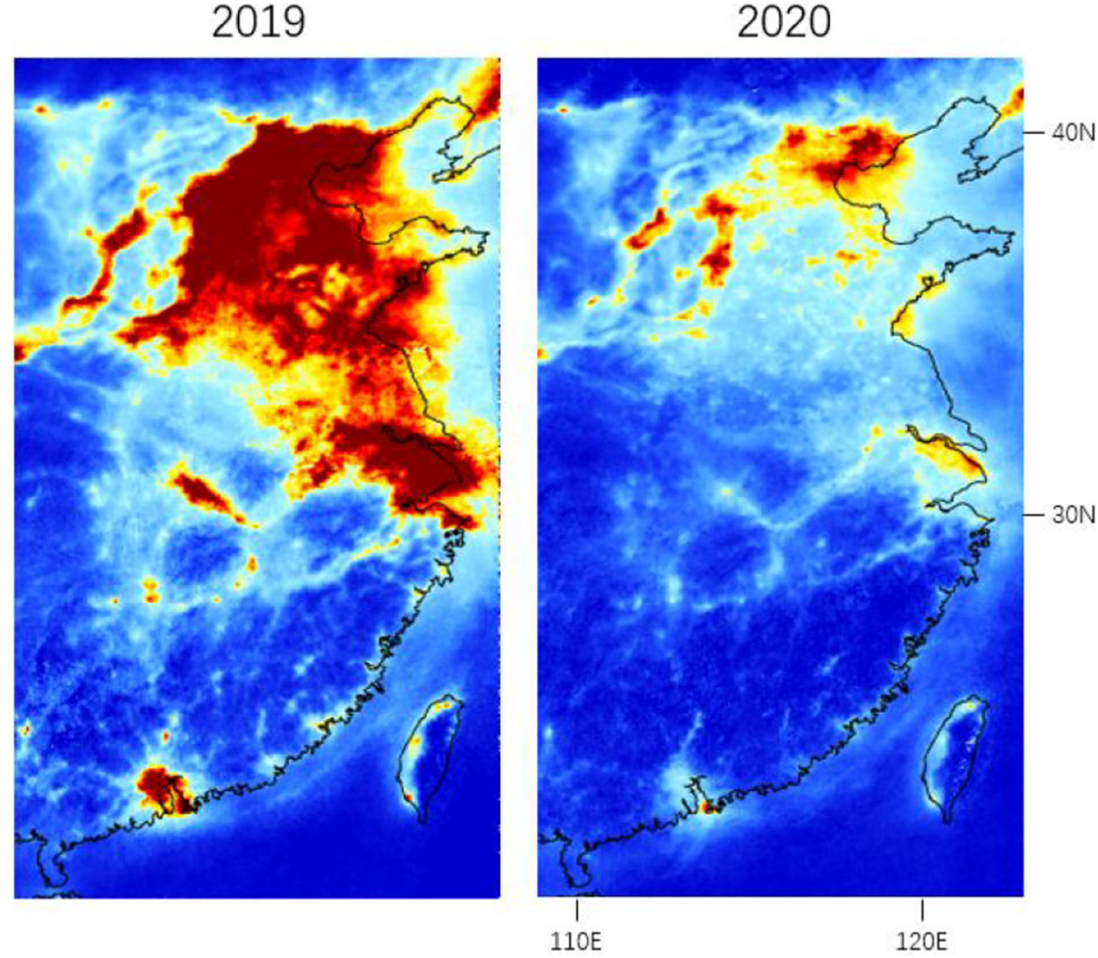

Tropospheric $\mathrm{NO}_{2}$ Column $\left[\times 10^{15} \mathrm{molec} / \mathrm{cm}^{2}\right]$

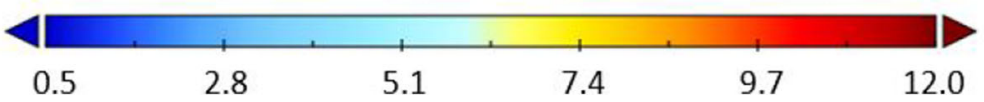


2020), consistent with regional studies using ground-based monitoring data (Wang et al. 2020; Silver et al. 2020; Lauri 2020) and emission data (Zheng et al. 2020a). Since the $2020 \mathrm{NO}_{2}$ data are lower by $31.8 \%$ than previous years before the lockdown period and $16.3 \%$ after the lockdown period, likely due to the pollution control policies (Liu et al. 2016; Wu et al. 2017), the lockdown effect over eastern China is estimated to induce a $\mathrm{NO}_{2}$ reduction of $30 \%$ on average.

Consistent daily variations of the retrieved $\mathrm{NO}_{2}$ amounts are found between GOME-2 and TROPOMI (Fig. S10 S12). For the urban and suburban Chinese regions, the $\mathrm{NO}_{2}$ measurements from GOME-2 are generally larger than TROPOMI due to the diurnal cycle of $\mathrm{NO}_{2}$, which is a function of diurnal variability in emissions, photochemistry, and boundary layer height (Penn and Holloway 2020). Attributed in part to emissions from commuter traffic, which peak in the morning and evening (Bower et al. 1991; Ketzel et al. 2003; Harley et al. 2005), the GOME-2 overpass could capture morning maximum $\mathrm{NO}_{2}$ columns (Fishman et al. 2008; Penn and Holloway 2020). In addition, the GOME-2 measurements are generally noisier as compared to TROPOMI results because of instrument degradation effects (Munro et al. 2016).

Figure 6 shows the corrected TROPOMI tropospheric $\mathrm{NO}_{2}$ over eastern China during the 2020 COVID-19 lockdown and the comparisons with columns in the same time periods in 2019. During the lockdown period, the TROPOMI $\mathrm{NO}_{2}$ declines across China, including the industrial regions and economic zones in the North, the major highways in the Center, and the shipping routes in the South.

Figure 7 presents the TROPOMI $\mathrm{NO}_{2}$ differences between 2020 and 2019 over eastern China for the prelockdown period (23 November of the previous year22 January), the peri-lockdown period (23 January-22 March), and the post-lockdown period (23 March-22 May). Table 1 quantifies the impact of the lockdown on corrected TROPOMI tropospheric $\mathrm{NO}_{2}$ columns at selected Chinese cities. The populated cities show strong reductions of tropospheric $\mathrm{NO}_{2}$ columns during lockdown, likely due to a combination of general improvements in air quality (reductions by up to 33\%) and COVID-19 lockdown impact (further reductions by $27-48 \%$ ). The estimated lockdown impact is consistent with Liu et al. (2020a), who observed a lockdown-related decrease of the operational TROPOMI $\mathrm{NO}_{2}$ data by $21 \pm 5 \%$ and concluded that the actual emission reduction is likely larger than the observed decrease due to the meteorological influence.

\section{Southern Europe}

As one of the first European countries hit hard by the COVID-19 pandemic, Italy imposed initial lockdown on 21 February 2020 in the most affected Lombardy region. The lockdown zone was extended to the northern provinces on 8 March and to the whole country on 9 March, making Italy the first European country to implement a nationwide lockdown. The lockdown restrictions were partially lifted from 4 May and further relaxed from 1 June.
Fig. 7 Differences in corrected TROPOMI tropospheric $\mathrm{NO}_{2}$ columns between 2020 and 2019 observed before $(23$ November of the previous year-22 January), during (23 January-22 March), and after (23 March-22 May) lockdown over eastern China
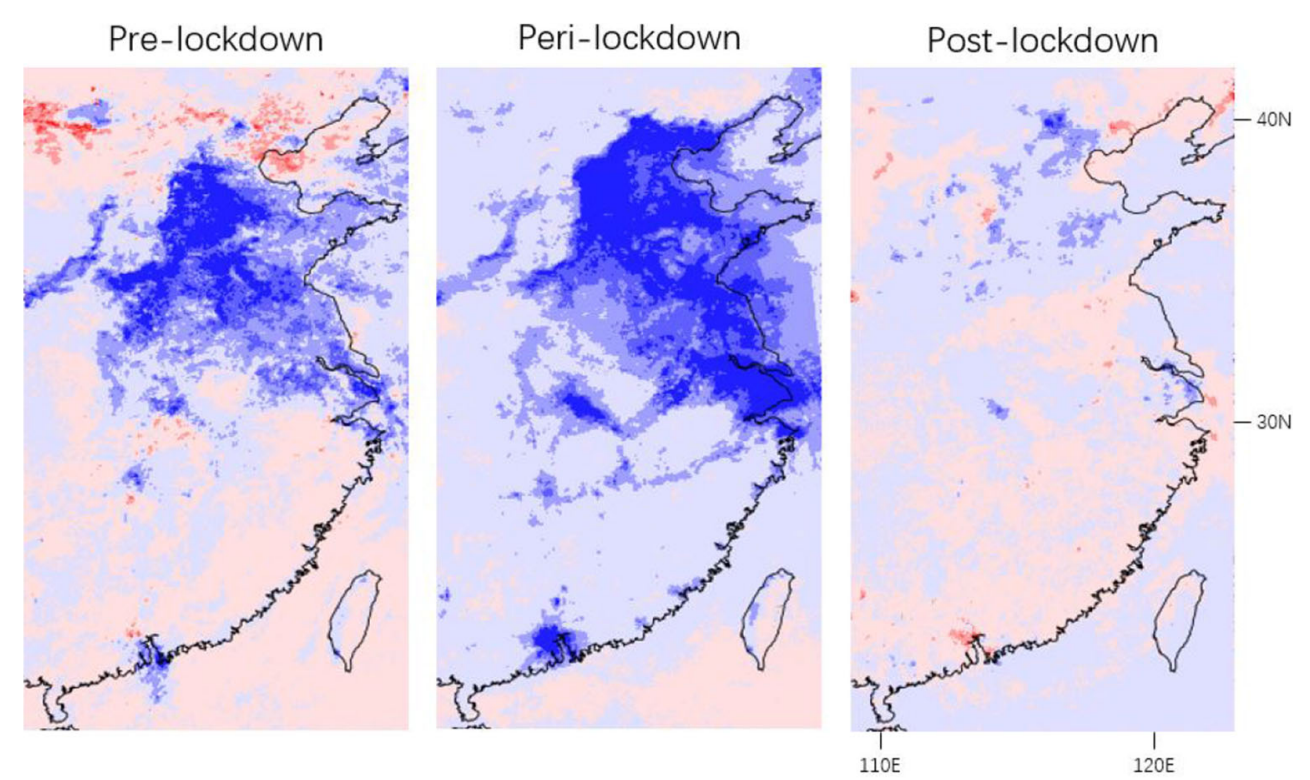

Tropospheric $\mathrm{NO}_{2}$ Column $\left[\times 10^{15} \mathrm{molec} / \mathrm{cm}^{2}\right]$

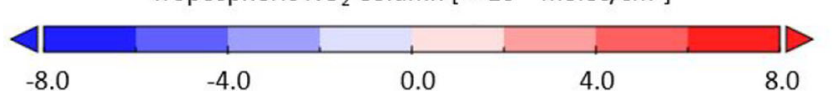


Table 1 Relative differences in the corrected tropospheric $\mathrm{NO}_{2}$ columns (\%) between 2020 and 2019 observed before, during, and after the COVID-19 lockdown for selected cities in Asia, Europe, North America, and South America

\begin{tabular}{|c|c|c|c|c|}
\hline Name & Location & Pre-lockdown & Peri-lockdown & Post-lockdown \\
\hline & & 23 Nov(last year)-22 Jan & 23 Jan-22 Mar & 23 Mar-22 May \\
\hline Beijing, China & $39.92^{\circ} \mathrm{N}, 116.42^{\circ} \mathrm{E}$ & -4.43 & -45.7 & -28.0 \\
\hline Shanghai, China & $31.17^{\circ} \mathrm{N}, 121.47^{\circ} \mathrm{E}$ & -33.1 & -60.5 & -15.0 \\
\hline \multirow[t]{2}{*}{ Wuhan, China } & $30.58^{\circ} \mathrm{N}, 114.28^{\circ} \mathrm{E}$ & -22.4 & -70.8 & -26.1 \\
\hline & & 16 Jan-15 Mar & 16 Mar-15 May & 16 May-15 Jul \\
\hline Barcelona, Spain & $41.38^{\circ} \mathrm{N}, 2.15^{\circ} \mathrm{E}$ & -13.1 & -62.4 & -31.3 \\
\hline Lisbon, Portugal & $38.73^{\circ} \mathrm{N}, 9.15^{\circ} \mathrm{W}$ & -22.7 & -49.6 & -18.4 \\
\hline Madrid, Spain & $40.43^{\circ} \mathrm{N}, 3.70^{\circ} \mathrm{W}$ & -21.4 & -59.9 & -37.1 \\
\hline Milan, Italy & $45.45^{\circ} \mathrm{N}, 9.17^{\circ} \mathrm{E}$ & -30.2 & -50.3 & -26.5 \\
\hline \multirow[t]{2}{*}{ Rome, Italy } & $41.90^{\circ} \mathrm{N}, 12.45^{\circ} \mathrm{E}$ & -12.9 & -44.5 & -28.4 \\
\hline & & 25 Jan-24 Mar & 25 Mar-24 Jun & 25 Jun-24 Jul \\
\hline New Delhi, India & $28.61^{\circ} \mathrm{N}, 77.21^{\circ} \mathrm{E}$ & -14.8 & -42.8 & -6.49 \\
\hline Mumbai, India & $19.00^{\circ} \mathrm{N}, 72.80^{\circ} \mathrm{E}$ & 1.45 & -41.3 & -19.5 \\
\hline \multirow[t]{2}{*}{ Waidhan, India } & $24.11^{\circ} \mathrm{N}, 82.65^{\circ} \mathrm{E}$ & -15.9 & -10.1 & -24.3 \\
\hline & & 16 Jan-15 Mar & 16 Mar-15 May & 16 May-15 Jul \\
\hline Los Angeles, USA & $34.05^{\circ} \mathrm{N}, 118.25^{\circ} \mathrm{W}$ & 4.81 & -33.0 & -29.6 \\
\hline New York, USA & $40.78^{\circ} \mathrm{N}, 73.97^{\circ} \mathrm{W}$ & -16.4 & -37.3 & -23.9 \\
\hline Philadelphia, USA & $39.95^{\circ} \mathrm{N}, 75.17^{\circ} \mathrm{W}$ & -20.8 & -28.2 & -23.5 \\
\hline San Francisco, USA & $37.78^{\circ} \mathrm{N}, 122.43^{\circ} \mathrm{W}$ & 11.7 & -36.7 & -29.6 \\
\hline \multirow[t]{2}{*}{ Washington DC, USA } & $38.88^{\circ} \mathrm{N}, 77.03^{\circ} \mathrm{W}$ & -23.5 & -31.3 & -27.3 \\
\hline & & 16 Jan-15 Mar & 16 Mar-15 May & 16 May-15 Jul \\
\hline Buenos Aires, Argentina & $34.58^{\circ} \mathrm{S}, 58.37^{\circ} \mathrm{W}$ & 13.0 & -26.1 & -4.36 \\
\hline Guayaquil, Ecuador & $2.17^{\circ} \mathrm{S}, 79.93^{\circ} \mathrm{W}$ & -11.4 & -45.1 & -5.19 \\
\hline Lima, Peru & $12.00^{\circ} \mathrm{S}, 77.03^{\circ} \mathrm{W}$ & 7.22 & -74.7 & -51.4 \\
\hline Santiago, Chile & $33.47^{\circ} \mathrm{S}, 70.7^{\circ} 5 \mathrm{~W}$ & -3.34 & -25.7 & -29.7 \\
\hline Sao Paulo, Brazil & $23.52^{\circ} \mathrm{S}, 46.52^{\circ} \mathrm{W}$ & 34.8 & -24.9 & -20.1 \\
\hline
\end{tabular}

Average tropospheric $\mathrm{NO}_{2}$ columns are calculated using TROPOMI data within a $0.5^{\circ} \times 0.5^{\circ}$ box around the city centers (latitudes and longitudes given in the table)

From Fig. 8, the corrected tropospheric $\mathrm{NO}_{2}$ columns from GOME-2A/B decrease by $\sim 20 \%$ for northern Italy before the lockdown compared to previous years, mainly caused by the emission control of the road transport and by the industrial combustion modification in Europe (Curier et al. 2014; Duncan et al. 2016; EEA 2019). The $\mathrm{NO}_{2}$ columns decline by $51.7 \%$ on average during the lockdown period in March-May and return to the level $\sim 20 \%$ lower compared to historical data in early June after the lockdown was eased. Considering the decrease before and after lockdown, the lockdown restriction measures likely contribute to an average $30 \%$ decline of the $\mathrm{NO}_{2}$ concentration for northern Italy.

Following Italy, European countries started to impose restrictions from mid-March with different severity and timing. Countries like Italy and Spain imposed strict lockdowns in response to the strong increase of infections, while others such as Germany and the Netherlands enacted relatively more relaxed measures. Countries like Portugal and Greece enforced proactive measures when cases were

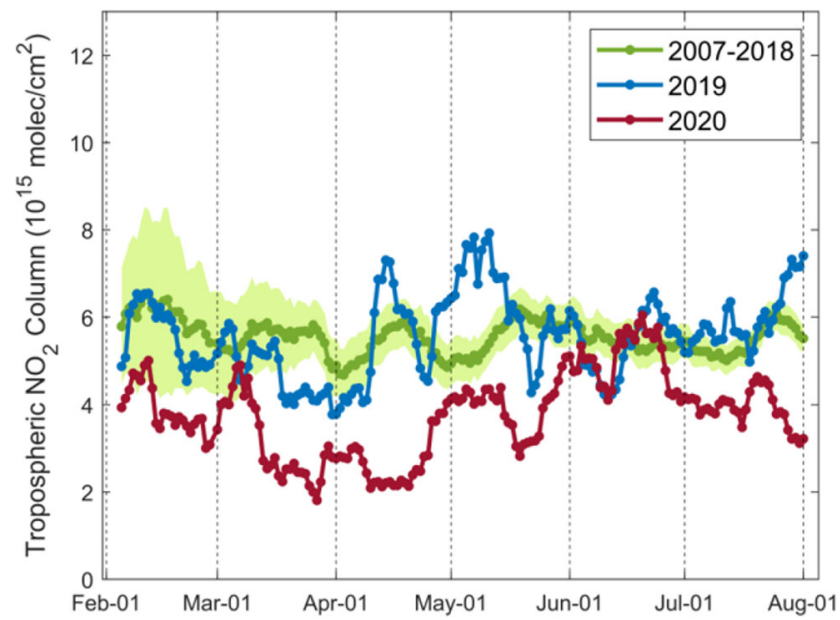

Fig. 8 Daily variations in 10-day moving averages of the corrected GOME-2A/B tropospheric $\mathrm{NO}_{2}$ columns over northern Italy $\left(45^{\circ} \mathrm{N}-\right.$ $46.5^{\circ} \mathrm{N}, 7^{\circ} \mathrm{E}-13^{\circ} \mathrm{E}$ ) for $2007-2018$ (green), 2019 (blue), and 2020 (red). Green shading shows standard error of the mean for 2007-2018. The COVID-19 pandemic lockdown starts on 8 March 2020 

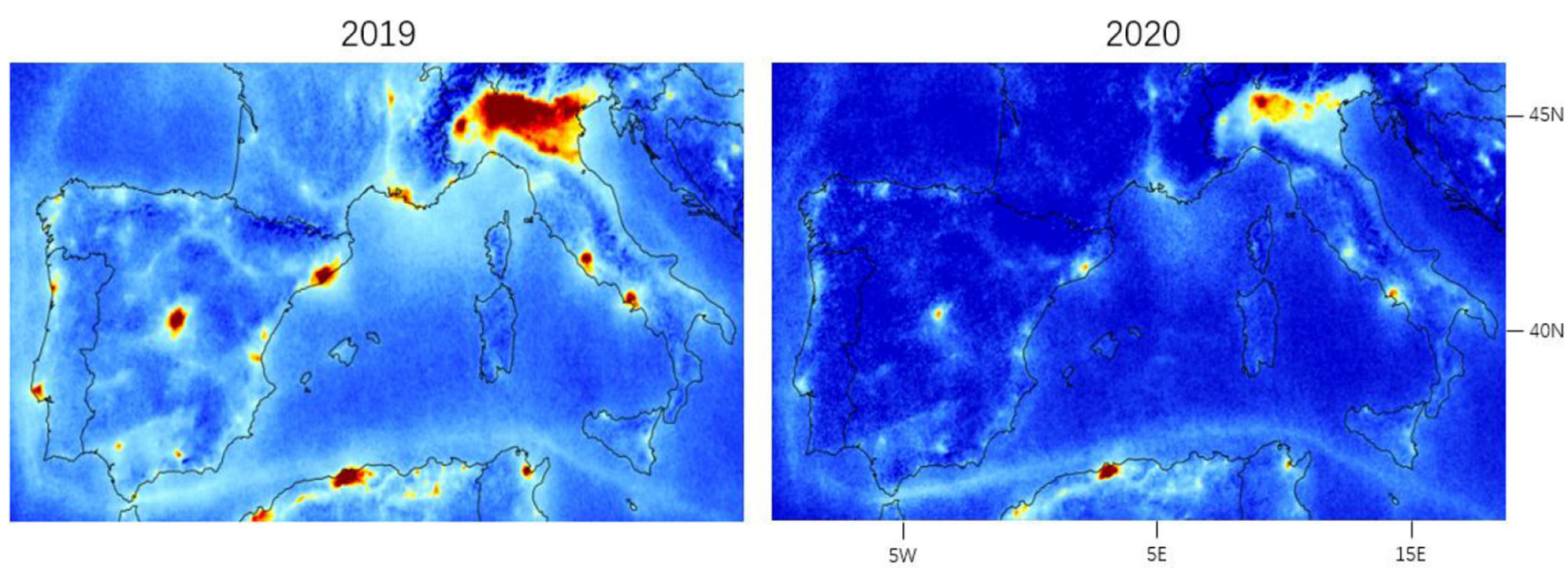

Tropospheric $\mathrm{NO}_{2}$ Column $\left[\times 10^{15} \mathrm{molec} / \mathrm{cm}^{2}\right]$

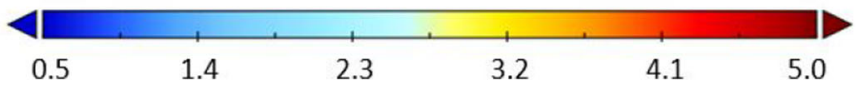

Fig. 9 Averages of the corrected tropospheric $\mathrm{NO}_{2}$ columns measured by TROPOMI over southern Europe during lockdown in $16 \mathrm{March}-15$ May in 2020 and comparison with columns in the same time period in 2019

low, while others including France and the UK took longer before imposing strict lockdowns.

For countries with strict and rapid lockdown measures in southern Europe, the drop in road traffic and industrial activities during the lockdown period leads to visible decreases of $\mathrm{NO}_{2}$ levels in most cities and highways in Figs. 9 and 10. The observed tropospheric $\mathrm{NO}_{2}$ columns in Table 1 are 12.9-30.2\% lower than the previous year before the implementation of the lockdown measures, 44.5$62.4 \%$ lower during lockdown, and 18.4-37.1\% lower after lockdown, indicating that the lockdown effect contributes to a $\sim 30 \%$ drop in $\mathrm{NO}_{2}$ over southern Europe.

\section{India}

India ordered a public curfew in response to the COVID19 outbreak on 22 March 2020, followed by a nationwide lockdown affecting 1.3 billion people on 25 March 2020. This large lockdown was extended to 30 June for containment zones and was eased in a phased manner in other zones from 8 Jun.

From Fig. 11, since the start of initial curfews and national restrictions in late March, the corrected GOME-2 tropospheric $\mathrm{NO}_{2}$ columns decrease by a factor of 3 by early April over the New Delhi region and remain low until June,

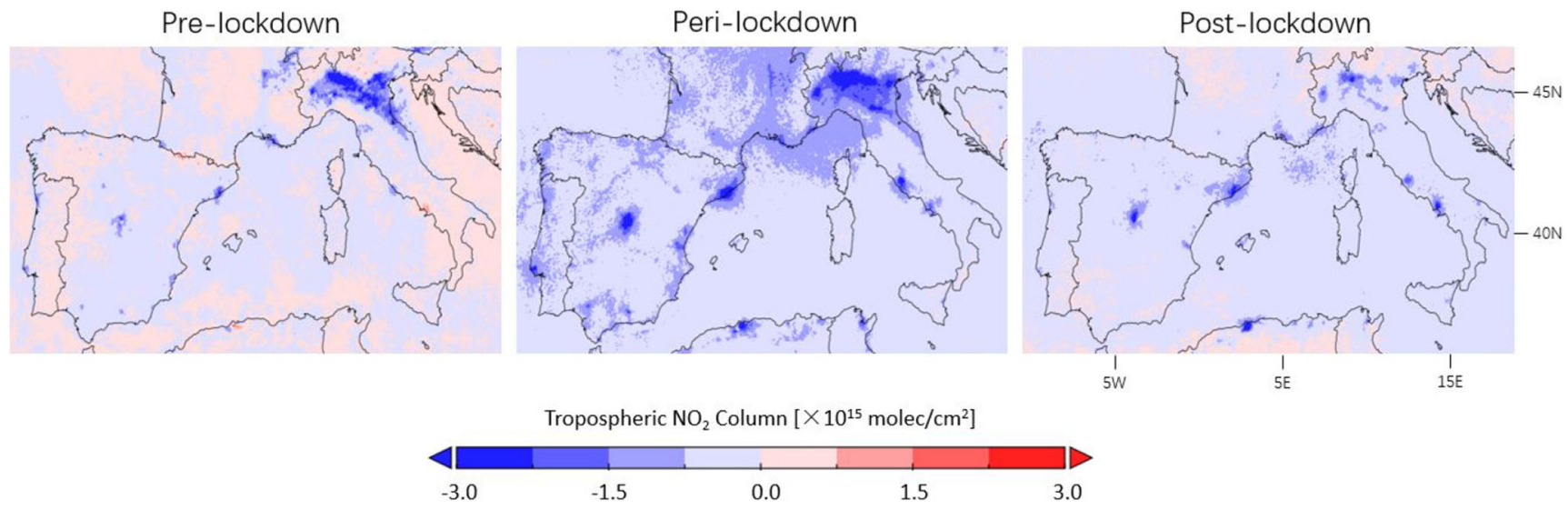

Fig. 10 Differences in corrected TROPOMI tropospheric $\mathrm{NO}_{2}$ columns between 2020 and 2019 observed before (16 January-15 March), during (16 March-15 May), and after (16 May-15 July) lockdown over southern Europe 


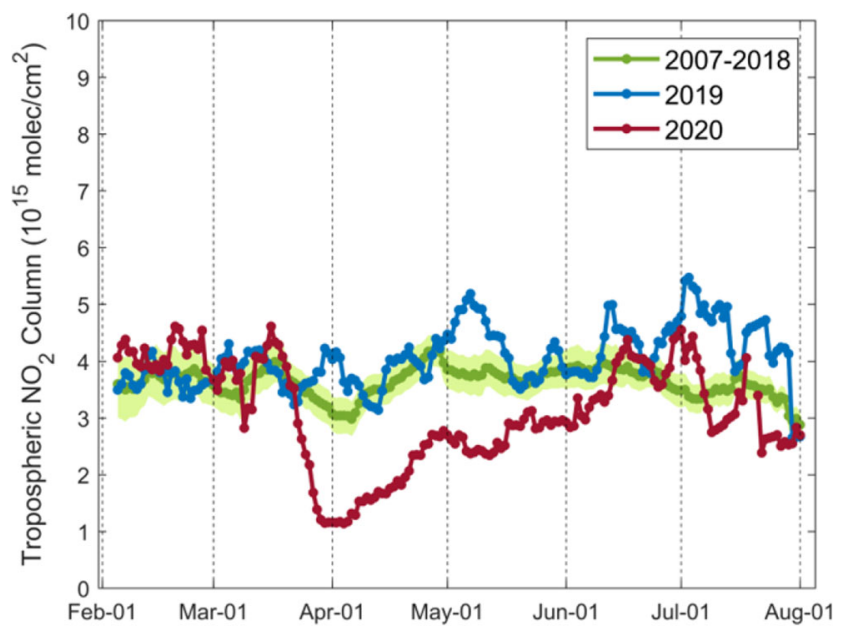

Fig. 11 Daily variations in 10-day moving averages of the corrected GOME-2A/B tropospheric $\mathrm{NO}_{2}$ columns over New Delhi in northern India $\left(27.6^{\circ} \mathrm{N}-29.6^{\circ} \mathrm{N}, 76.2^{\circ} \mathrm{E}-78.2^{\circ} \mathrm{E}\right.$ ) for $2007-2018$ (green), 2019 (blue), and 2020 (red). Green shading shows standard error of the mean for 2007-2018. The COVID-19 pandemic lockdown starts on 25 March 2020

not only in comparison with values before the lockdown but also compared to an identical period in the historical data. The declines for New Delhi during the lockdown period are up to $65.2 \%$ compared to previous years. Good agreement is observed between GOME-2 and TROPOMI data (Fig. S11).
From Figs. 12 and 13, lockdown-related declines of TROPOMI tropospheric $\mathrm{NO}_{2}$ columns are observed for the Indo-Gangetic Plain in the North with a large population as well as the Chhattisgarh state in the Center and the Tamil Nadu state in the South with electricity production activities (Hilboll et al. 2017). From Table 1, the $\mathrm{NO}_{2}$ values decrease by $42 \%$ on average for populated cities such as New Delhi and Mumbai for the lockdown period compared to the same time in 2019, which is $35.4 \%$ lower than the pre-lockdown drops. For the Waidhan City with the largest Indian power station (the Vindhyachal Super Thermal Power Station), lockdown-related variations of no more than $14.2 \%$ are found in the TROPOMI dataset due to the continuous operations to procure coal-powered energy, an essential commodity during the lockdown period (Sharma et al. 2020; Mahato et al. 2020).

\section{The USA}

The USA local and statewide restriction measures first began to come into effect from mid-March 2020 in affected areas like California. The Californian lockdown started first on 12 March to limit non-essential gatherings and extended to the entire state on 19 March. The restrictions were initially lifted from 8 May and further relaxed from 5 June. As of July 2020, however, California re-imposed the
Fig. 12 Averages of the corrected tropospheric $\mathrm{NO}_{2}$ columns measured by TROPOMI over India during lockdown in 25 March-24 June in 2020 and comparison with columns in the same time period in 2019
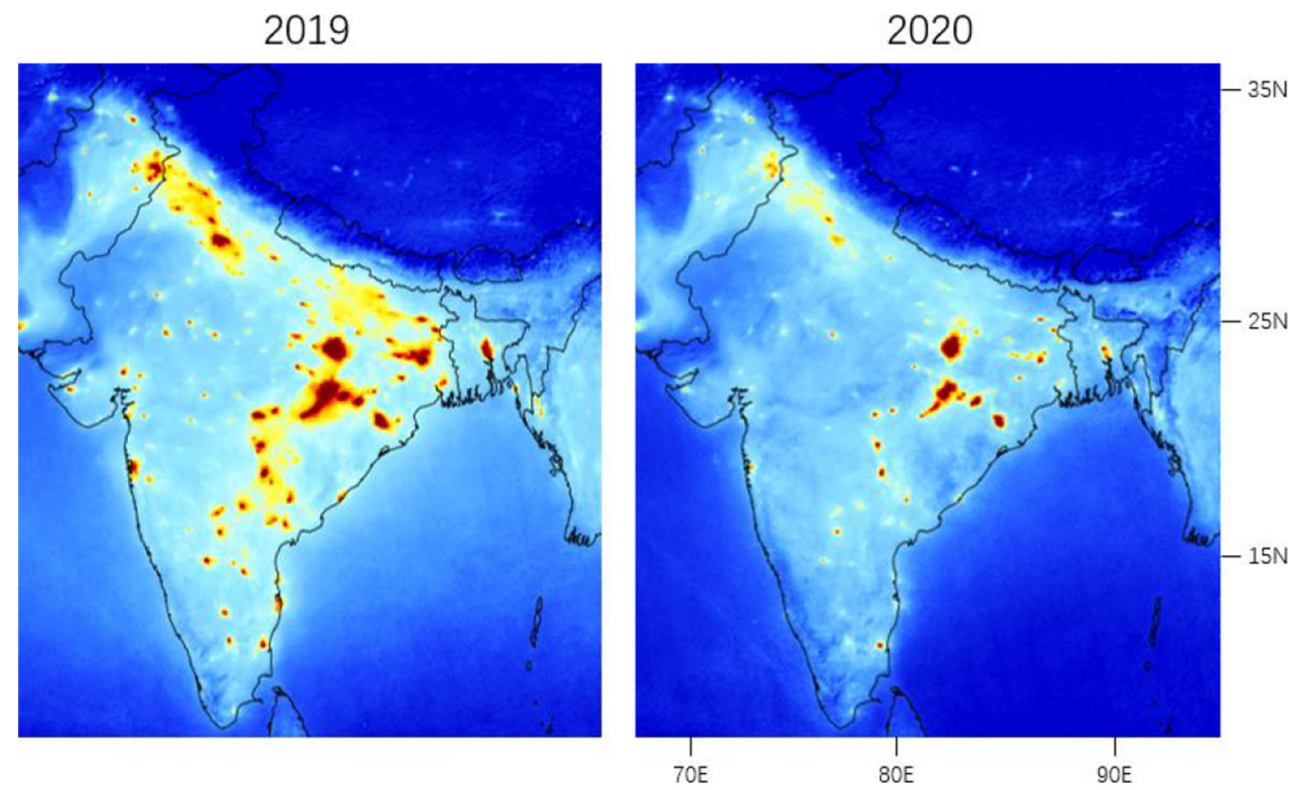

Tropospheric $\mathrm{NO}_{2}$ Column $\left[\times 10^{15} \mathrm{molec} / \mathrm{cm}^{2}\right]$

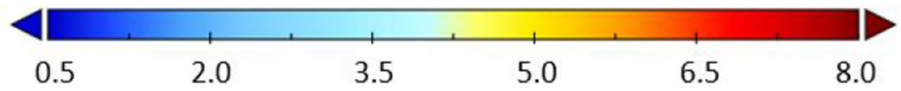



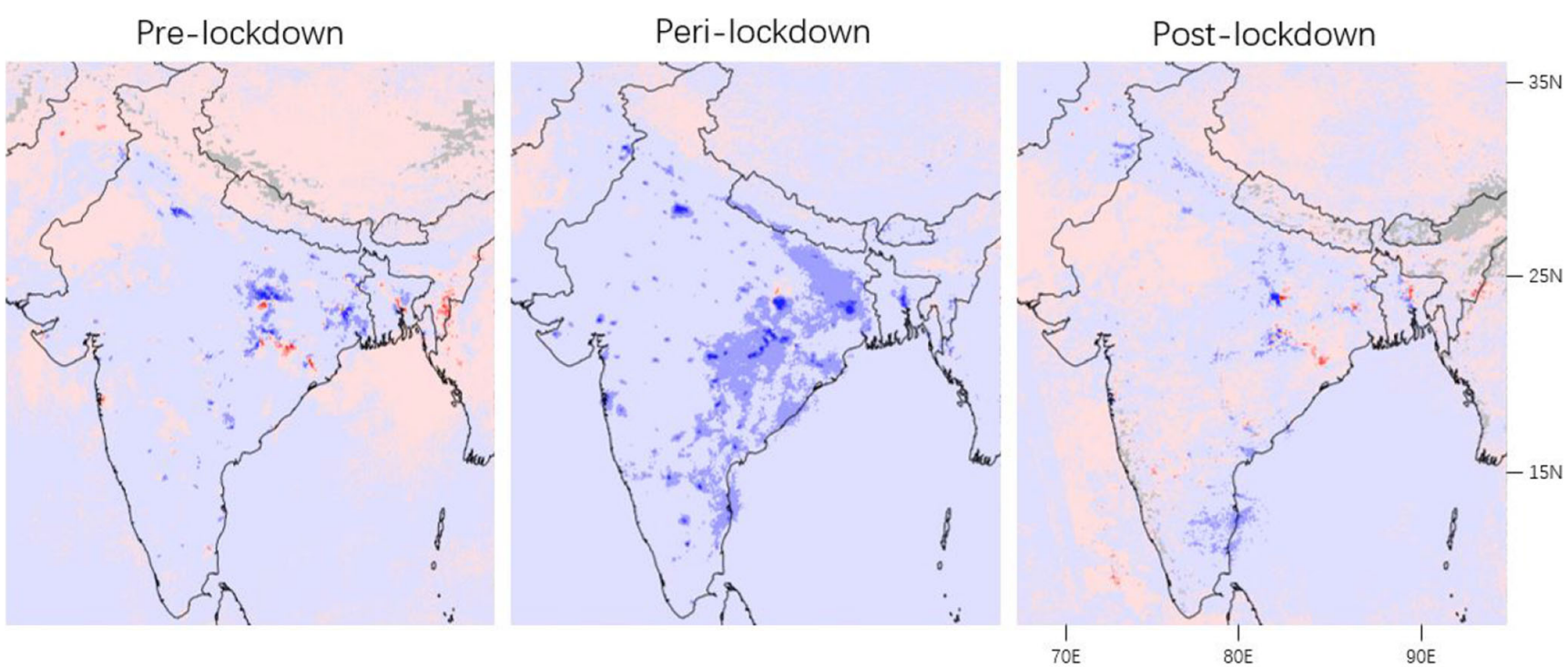

Tropospheric $\mathrm{NO}_{2}$ Column $\left[\times 10^{15} \mathrm{molec} / \mathrm{cm}^{2}\right]$

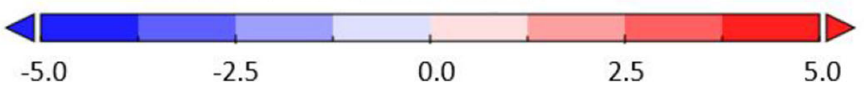

Fig. 13 Differences in corrected TROPOMI tropospheric $\mathrm{NO}_{2}$ columns between 2020 and 2019 observed before (25 January-24 March), during (25 March-24 June), and after (25 June-24 July) lockdown over India

lockdown measures, when the highest number of confirmed infections in the USA was reported.

The corrected $\mathrm{NO}_{2}$ concentrations from GOME-2 decline by $20 \%$ on 12 March for Los Angeles in Fig. 14 as the initial COVID-19 measures were adopted. Compared to the historical data, the $\mathrm{NO}_{2}$ concentrations are decreased by $31.1 \%$ on average during the first month of lockdown

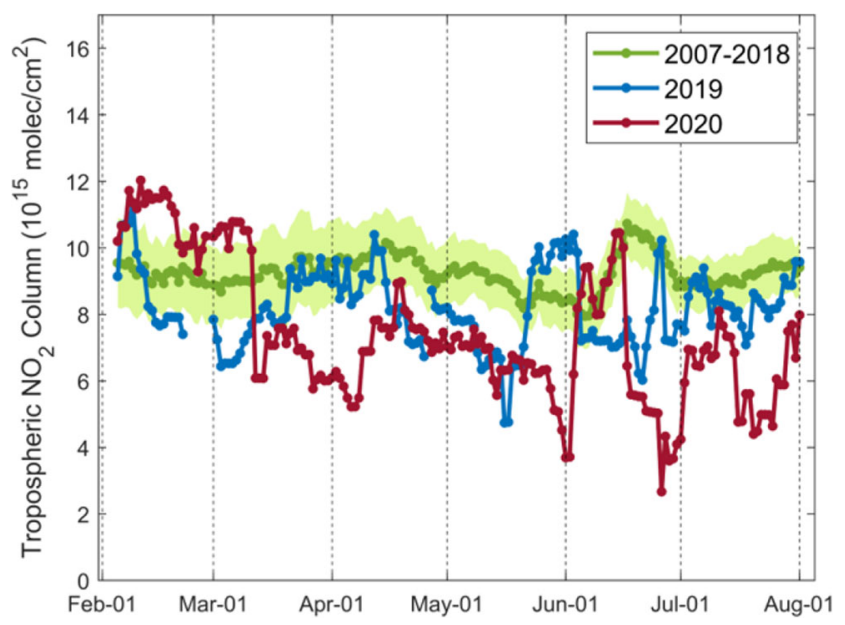

Fig. 14 Daily variations in 10-day moving averages of the corrected GOME-2A/B tropospheric $\mathrm{NO}_{2}$ columns over Los Angeles in the southwestern USA $\left(33.5^{\circ} \mathrm{N}-35.5^{\circ} \mathrm{N}, 117.25^{\circ} \mathrm{W}-119.25^{\circ} \mathrm{W}\right)$ for $2007-$ 2018 (green), 2019 (blue), and 2020 (red). Green shading shows standard error of the mean for 2007-2018. The COVID-19 pandemic lockdown starts on 12 March 2020 and $26.0 \%$ during the second month. The (much-)aboveaverage to record precipitation in 2020 (https://www.ncdc. noaa.gov/sotc/national/202003) can contribute to the $\mathrm{NO}_{2}$ variations, but the impact is expected to be partially corrected by the wind correction introduced in "Trend, seasonal, and meteorological corrections". In early June, the strong increases of tropospheric $\mathrm{NO}_{2}$ columns can be explained by the presence of a number of bush fires (https:// www.lafd.org/alerts). Afterwards the $\mathrm{NO}_{2}$ levels remain low compared to the historical data, because the lockdown measures were re-imposed due to a significant increase of infection cases.

Similar variations are observed for TROPOMI measurements in Fig. S11. However, as compared to the relatively large regions with high pollution levels in "China"-India, Los Angeles shows less pronounced agreement between GOME-2 and TROPOMI data due to heterogeneous topography and isolation from urban agglomeration. In addition, a stronger dependency of local $\mathrm{NO}_{2}$ amount on wind fields is observed for TROPOMI (Fig. S12) than GOME-2 (Fig. S9). For Los Angeles, GOME-2 averages the high concentrations of the plume with the lower surrounding concentrations over a larger pixel size.

The lockdown causes decreases of TROPOMI $\mathrm{NO}_{2}$ levels for major cities in California's Central Valley, the San Francisco Bay Area, and the Greater Los Angeles Area as compared to 2019 in Figs. 15 and 16. The mean decline observed during the lockdown period for California is $34.9 \%$ in Table 1, consistent with the estimations of 32.5 
Fig. 15 Averages of the corrected tropospheric $\mathrm{NO}_{2}$ columns measured by TROPOMI over southwestern USA during lockdown in 16 March-15 May in 2020 and comparison with columns in the same time period in 2019

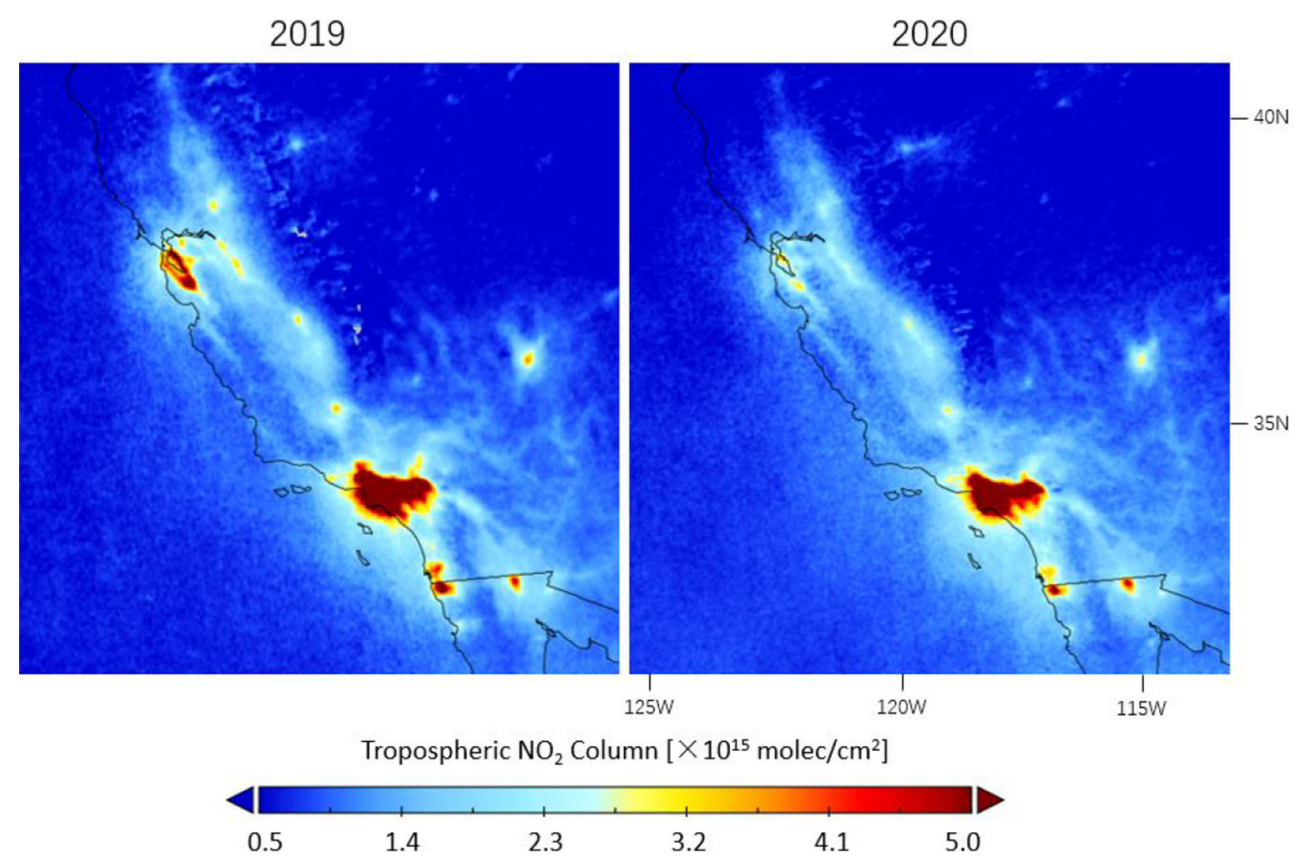

to $40.7 \%$ from Goldberg et al. (2020b) using the operational TROPOMI product and accounting for the meteorological effect. The $\mathrm{NO}_{2}$ columns recover only slightly by $5.2 \%$ between the peri- and post-lockdown periods, which can be related to the implementation of the re-lockdown, requiring future observations for a robust analysis. In comparison with California, the lockdown-related $\mathrm{NO}_{2}$ variations are less significant in the eastern USA in Table 1. The $\mathrm{NO}_{2}$ drops due to COVID-19 precautions are estimated to range between 7.4 and $17.8 \%$ considering the decline in the prelockdown period, and the $\mathrm{NO}_{2}$ rebounds range between 4.0 and $10.3 \%$.

\section{South America}

Most countries affected by COVID-19 in South America imposed quarantine restrictions starting from mid-March to
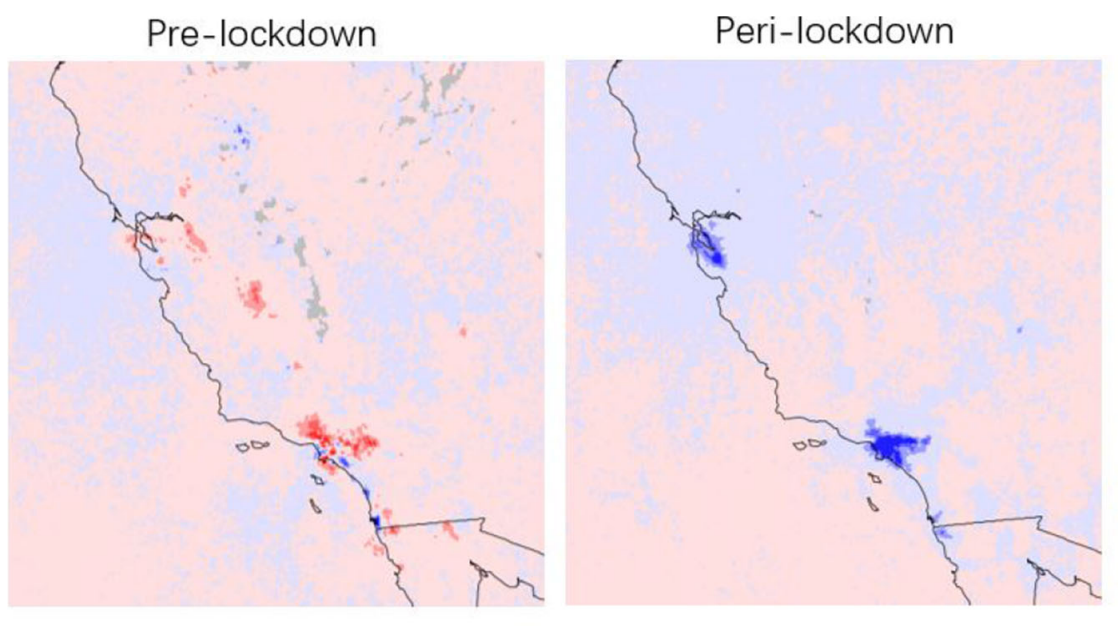

Tropospheric $\mathrm{NO}_{2}$ Column $\left[\times 10^{15} \mathrm{molec} / \mathrm{cm}^{2}\right]$
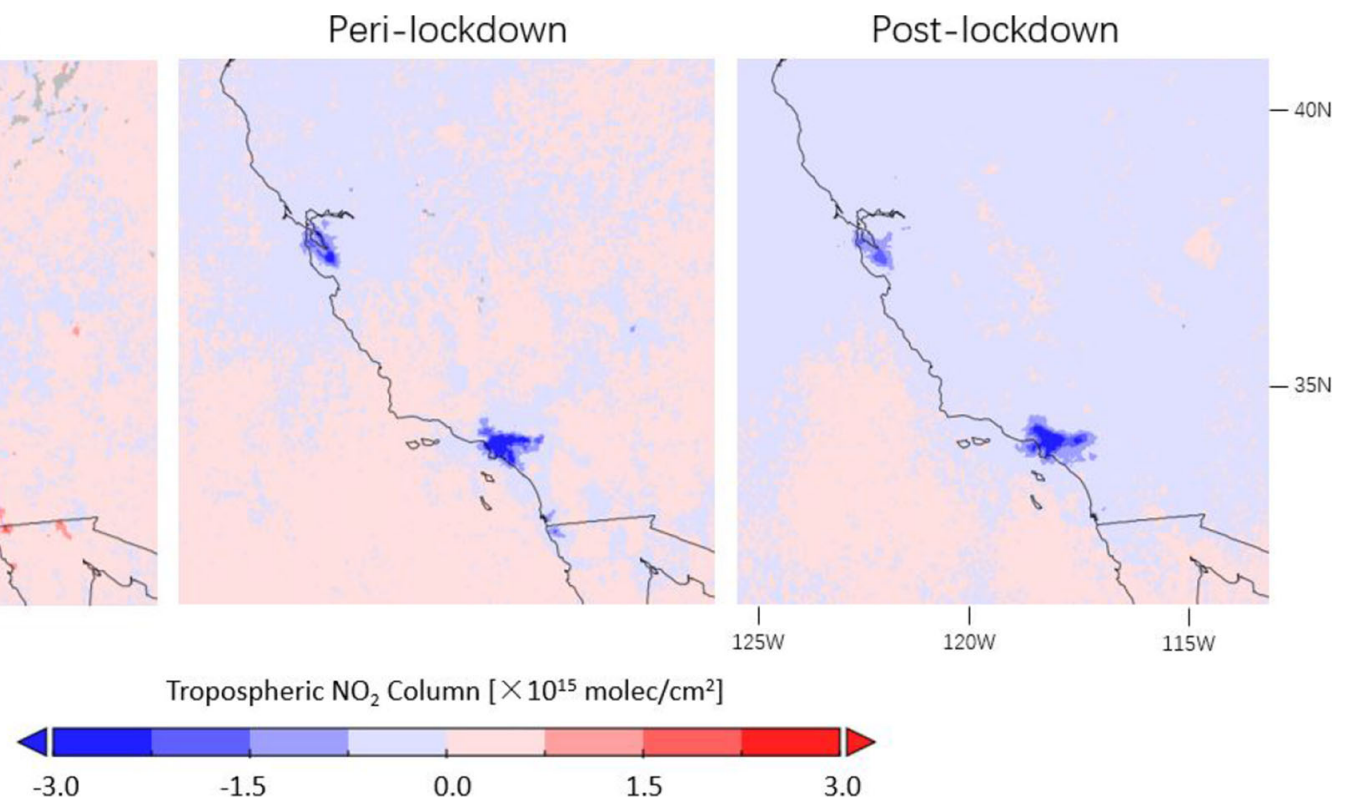

Fig. 16 Differences in corrected TROPOMI tropospheric $\mathrm{NO}_{2}$ columns between 2020 and 2019 observed before (16 January-15 March), during (16 March-15 May), and after (16 May-15 July) lockdown over southwestern US 


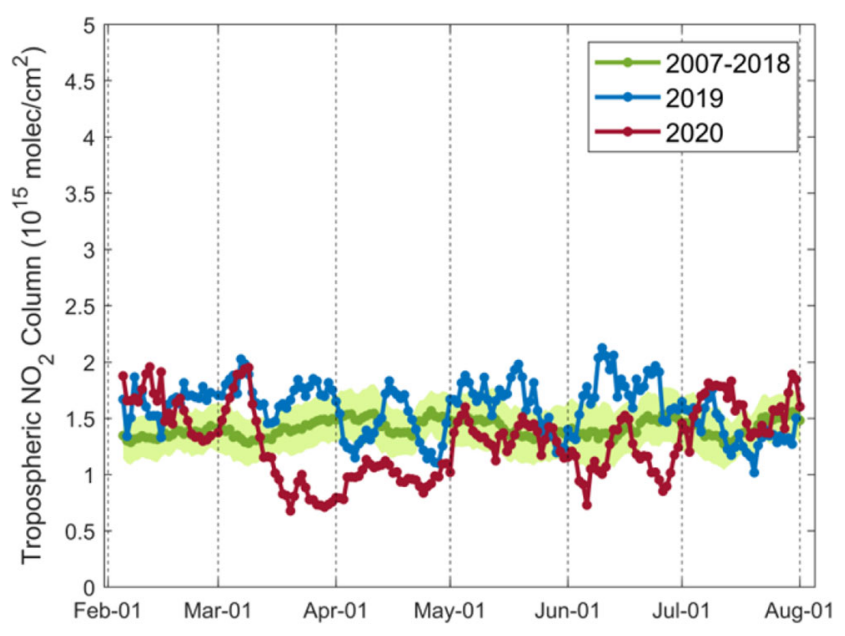

Fig. 17 Daily variations in 10-day moving averages of the corrected GOME-2A/B tropospheric $\mathrm{NO}_{2}$ columns over Lima in Peru $\left(11^{\circ} \mathrm{S}-\right.$ $13^{\circ} \mathrm{S}, 76^{\circ} \mathrm{W}-78^{\circ} \mathrm{W}$ ) for $2007-2018$ (green), 2019 (blue), and 2020 (red). Green shading shows standard error of the mean for 2007-2018. The COVID-19 pandemic lockdown starts on 15 March 2020

slow down the rapid increase of infections, such as regional lockdowns in Brazil and Chile and national lockdowns in Ecuador, Argentina, and Peru.

Starting on 15 March 2020 with the announcement of one of the earliest and strictest lockdown measures in South America, declines of the GOME-2 tropospheric $\mathrm{NO}_{2}$ columns by up to $54.3 \%$ are found for the Lima area of Peru in late March and April 2020 in Fig. 17. As a four-step plan on a monthly basis to reopen the economy was announced in early May 2020, the $\mathrm{NO}_{2}$ levels return to the normal range and differ within $\pm 20 \%$ afterwards. Compared to TROPOMI data (Fig. S11), the larger noise in the $\mathrm{NO}_{2}$ columns from GOME-2 is attributed to the larger effect of the Southern Atlantic Anomaly (SAA), where an anomaly in the Earth's magnetic field leads to enhanced radiation exposure of the MetOp satellites (Richter et al. 2011; Fioletov et al. 2020).

The implementation of lockdown measures decreases the TROPOMI tropospheric $\mathrm{NO}_{2}$ columns for most South American urban areas in Figs. 18 and 19. Local $\mathrm{NO}_{2}$ increases can be attributed to active biomass burning in rural regions, for instance, the $\mathrm{NO}_{2}$ enhancements by up to $1 \times 10^{15} \mathrm{molec} / \mathrm{cm}^{2}$ over Argentina and Paraguay during lockdown are likely related to fires for agricultural use (https://modis.gsfc.nasa.gov/gallery/individual.php?db date=2020-04-21). Comparing the peri-lockdown $\mathrm{NO}_{2}$ drops with pre-lockdown values in Table 1 , the declines resulted from the lockdown are $39.1 \%$ for Buenos Aires in Argentina, 33.7\% for Guayaquil in Ecuador, $81.9 \%$ for Lima in Peru, $22.4 \%$ for Santiago in Chile, and $59.7 \%$ for Sao Paulo in Brazil. During the post-lockdown timeframe, the $\mathrm{NO}_{2}$ levels rebound by $\sim 20 \%$ in Lima but to lower levels than the pre-lockdown timeframe. A return to the normal $\mathrm{NO}_{2}$ level is found for Guayaquil and Buenos Aires, but the comparison in Argentina is complicated due to the increase in fire activity, which is visible from the increased tropospheric $\mathrm{NO}_{2}$ columns during the post-lockdown period in Fig. 19 over Paraná River Basin (https://earthobservatory. nasa.gov/images/147031/the-parched-parana-river). While
Fig. 18 Averages of the corrected tropospheric $\mathrm{NO}_{2}$ columns measured by TROPOMI over South America during lockdown in 16 March-15 May in 2020 and comparison with columns in the same time period in 2019
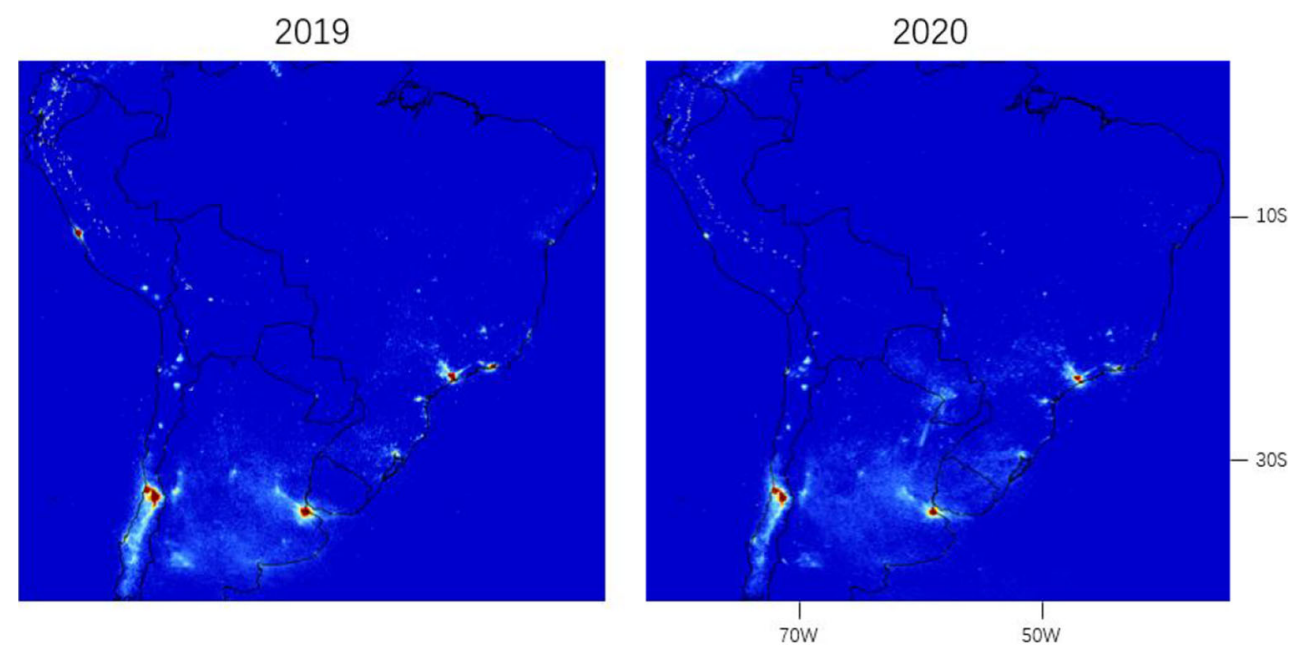

Tropospheric $\mathrm{NO}_{2}$ Column $\left[\times 10^{15} \mathrm{molec} / \mathrm{cm}^{2}\right]$

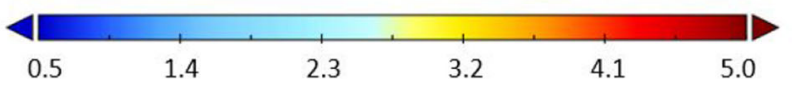




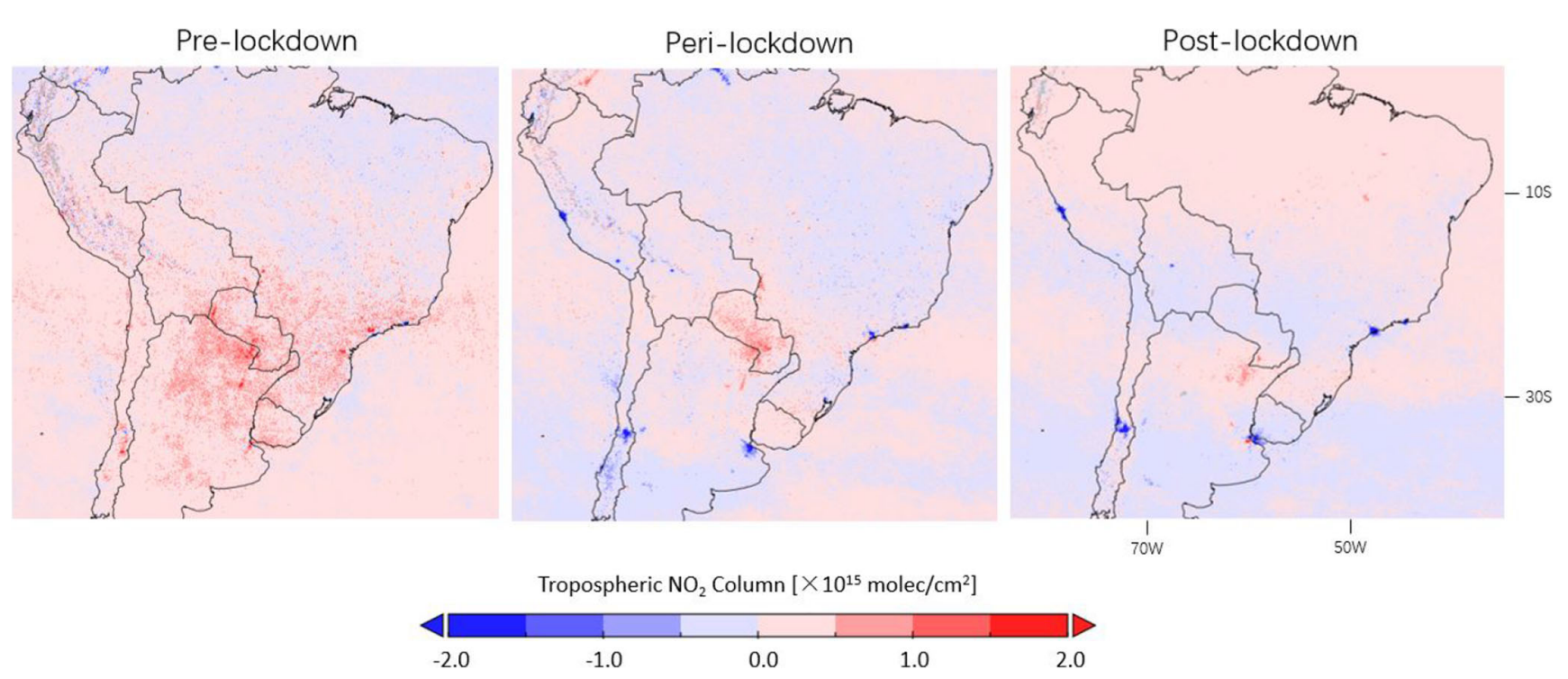

Fig. 19 Differences in corrected TROPOMI tropospheric $\mathrm{NO}_{2}$ columns between 2020 and 2019 observed before (16 January-15 March), during (16 March-15 May), and after (16 May-15 July) lockdown over South America

a number of regions remain the current epicenters of the COVID-19 pandemic, regional studies with longer $\mathrm{NO}_{2}$ time series will be the subject of future work.

\section{Conclusion}

In response to the rapid COVID-19 spread, countries around the world have imposed lockdown restrictions. Quantifying the temporal changes of pollutant concentrations due to COVID19 restrictions is important to understand the impact of public health measures on environment, economy, and society.

Mainly emitted anthropogenically from the road transport and industrial activities, the variations of tropospheric $\mathrm{NO}_{2}$ columns are analyzed based on the long-term global dataset (since 2007) from GOME-2 with a morning overpass and the high-resolution measurements $(5.5 \mathrm{~km} \times 3.5$ $\mathrm{km})$ from TROPOMI with an early afternoon overpass. The GOME-2 and TROPOMI $\mathrm{NO}_{2}$ data are retrieved in a harmonized manner and corrected for trend, season, and meteorology using a statistical method.

With good consistency between GOME-2 and TROPOMI measurements, strong decreases in tropospheric $\mathrm{NO}_{2}$ columns are observed during the lockdown period not only in comparison with levels before and after the lockdown but also compared to identical periods in the historical data. China observes an average $24.1 \%$ decline of $\mathrm{NO}_{2}$ levels due to the pollution control policies and a further reduction of $\sim 30 \%$ due to the COVID-19 containment measures after the Chinese New Year holiday in late January 2020. The $\mathrm{NO}_{2}$ amount gradually returns to the normal level as previous years after 2 months of lockdown. Similar decline and rebound are observed for southern
European countries such as Italy, Portugal, and Spain, where the mean $\mathrm{NO}_{2}$ decline because of emission control is $\sim 20 \%$ and the lockdown-related drop during mid-March to mid-May is $\sim 30 \%$. In India, the tropospheric $\mathrm{NO}_{2}$ columns decrease by $42 \%$ on average for populated areas and by up to $14.2 \%$ for particular power plant locations, followed by a rebound in late June after 3 months of lockdown. The USA reports a lockdown-related $\mathrm{NO}_{2}$ reduction of $34.9 \%$ on average for western regions such as California and up to $17.8 \%$ for eastern areas. In South America, the tropospheric $\mathrm{NO}_{2}$ columns reduce by up to $81.9 \%$ during mid-March to mid-May due to the lockdown.

In conclusion, the $\mathrm{NO}_{2}$ drops due to the lockdown restrictions are estimated to be $30 \%$ for populated cities in China and southern Europe, $42 \%$ in India, 35\% in the southwestern USA, and $48 \%$ in South America. Due to the recovery of social and economic activities in a phased manner, gradual rebounds of the tropospheric $\mathrm{NO}_{2}$ columns to normal levels are found for countries such as China, Italy, and India. As the lockdown is still ongoing for a number of regions worldwide in response to the second wave of outbreak, and its long-term effect on $\mathrm{NO}_{2}$ variations (e.g., due to the possible economic downturn) is uncertain, a further monitoring of the $\mathrm{NO}_{2}$ concentration recovery will be necessary.

Supplementary Information The online version contains supplementary material available at https://doi.org/10.1007/s11869-021-01046-2.

Acknowledgements This work is undertaken in the framework of the EUMETSAT AC SAF project and the S-VELD project. The operational GOME-2 $\mathrm{NO}_{2}$ data are provided by DLR in the framework of the EUMETSAT AC SAF project. The TROPOMI $\mathrm{NO}_{2}$ data generated with the DLR retrieval algorithm are used in the S-VELD project, which is financed by the Federal Ministry of Transport and 
Digital Infrastructure to analyze the effect of traffic emission on air quality in Germany. We thank EUMETSAT for the provision of the GOME-2 level 1 products and EU/ESA/KNMI/DLR for the provision of the TROPOMI/S5P level 1 products and the operational TROPOMI/S5P $\mathrm{NO}_{2}$ products via the Copernicus Open Access Hub (https://scihub.copernicus.eu/). We thank DLR colleagues for developing the Universal Processor for UV/Vis Atmospheric Spectrometers (UPAS) system used for generating level 2 products from GOME-2 and TROPOMI. We acknowledge the free use of the ERA5 data from the Copernicus Climate Change (C3S) climate data store (https://cds.climate.copernicus.eu/). This paper contains modified Copernicus Sentinel data processed by DLR.

Funding Open Access funding enabled and organized by Projekt DEAL. This research has been financially supported by the DLR/DAAD Research Fellowships programme organized by the German Academic Exchange Service (DAAD) and the German Aerospace Center (DLR): DLR/DAAD Research Fellowships Postdocs programme (57478192).

Data availability The GOME- $2 \mathrm{NO}_{2}$ AC SAF data provided by DLR can be ordered via the EUMETSAT Data Centre (https://acsaf.org/). The TROPOMI $\mathrm{NO}_{2}$ dataset used in the study is available upon request.

\section{Declarations}

Conflict of interest The authors declare no competing interests.

Open Access This article is licensed under a Creative Commons Attribution 4.0 International License, which permits use, sharing, adaptation, distribution and reproduction in any medium or format, as long as you give appropriate credit to the original author(s) and the source, provide a link to the Creative Commons licence, and indicate if changes were made. The images or other third party material in this article are included in the article's Creative Commons licence, unless indicated otherwise in a credit line to the material. If material is not included in the article's Creative Commons licence and your intended use is not permitted by statutory regulation or exceeds the permitted use, you will need to obtain permission directly from the copyright holder. To view a copy of this licence, visit http://creativecommons. org/licenses/by/4.0/.

\section{References}

Baldasano JM (2020) COVID-19 lockdown effects on air quality by $\mathrm{NO}_{2}$ in the cities of Barcelona and Madrid (spain). Sci Total Environ 741:140353. https://doi.org/10.1016/j.scitotenv.2020.140353

Bansal G, Bandivadekar A (2013) Overview of India?s vehicle emissions control program. Tech. Rep., The International Council on Clean Transportation, www.theicct.org/india

Bauwens M, Compernolle S, Stavrakou T, Müller J-F, van Gent J, Eskes H, Levelt PF, vander A RJ, Veefkind JP, Vlietinck J, Yu H, Zehner C (2020) Impact of coronavirus outbreak on $\mathrm{NO}_{2}$ pollution assessed using tropomi and omi observations. Geophys Res Lett 47(11):e2020GL087978. https://doi.org/10.1029/2020GL087978

Beirle S, Borger C, Dörner S, Li A, Hu Z, Liu F, Wang Y, Wagner T (2019) Pinpointing nitrogen oxide emissions from space. Sci Adv 5(11):eaax9800. https://doi.org/10.1126/sciadv.aax9800

Beirle S, Hörmann C, Jöckel P, Liu S, Penning de Vries M, Pozzer A, Sihler H, Valks P, Wagner T (2016) The stratospheric estimation algorithm from mainz (stream): estimating stratospheric $\mathrm{NO}_{2}$ from nadir-viewing satellites by weighted convolution. Atmos Meas Tech 9(7):2753-2779. https://doi.org/10.5194/amt-9-2753-2016

Bekbulat B, Apte J, Millet D, Robinson A, Wells K, Marshall J (2020) PM2.5 and ozone air pollution levels have not dropped consistently across the US following societal COVID response. https:// doi.org/10.26434/chemrxiv.12275603.v1

Bovensmann H, Burrows JP, Buchwitz M, Frerick J, Rozanov VV, Chance KV, Goede APH (1999) Sciamachy: mission objectives and measurement modes. J Atmos Sci 56:127-150. https://doi. org/10.1175/1520-0469(1999)056<0127:SMOAMM > 2.0.CO;2

Bower JS, Broughton GFJ, Dando MT, Lees AJ, Stevenson KJ, Lampert JE, Sweeney BP, Parker VJ, Driver GS, Waddon CJ, Wood AJ (1991) Urban $\mathrm{NO}_{2}$ concentrations in the UK in 1987. Atmos Environ B Urban Atmos 25(2):267-283. https://doi.org/10.1016/09571272(91)90062-J

Burrows JP, Weber M, Buchwitz M, Rozanov V, LadstätterWeißenmayer A, Richter A, DeBeek R, Hoogen R, Bramstedt K, Eichmann K-U, Eisinger M, Perner D (1999) The global ozone monitoring experiment (gome): mission concept and first scientific results. J Atmos Sci 56(2):151-175. https://doi.org/10.1175/ 1520-0469(1999)056<0151:TGOMEG > 2.0.CO;2

CAAC (2013) Caac (clean air alliance of china) state council air pollution prevention and control action plan. Tech. Rep., issue II, www.cleanairchina.org

Callies J, Corpaccioli E, Eisinger M, Hahne A, Lefebvre A (2000) Gome-2-metop's second-generation sensor for operational ozone monitoring. ESA bulletin 102:28-36

Cermak J, Wild M, Knutti R, Mishchenko MI, Heidinger AK (2010) Consistency of global satellite-derived aerosol and cloud data sets with recent brightening observations. Geophys Res Lett 37(21):L21704. https://doi.org/10.1029/2010GL044632

Chen J, Jiang Z, Miyazaki K, Zhu R, Chen X, Liao C, Jones D, Bowman K, Sekiya T (2020) Impacts of COVID-19 control measures on tropospheric $\mathrm{NO}_{2}$ over China, South Korea and Italy. arXiv:2006.12858

Compernolle S, Argyrouli A, Lutz R, Sneep M, Lambert J-C, Fjæraa AM, Hubert D, Keppens A, Loyola DG, O'Connor E, Romahn F, Stammes P, Verhoelst T, Wang P (2020) Validation of the sentinel5 precursor tropomi cloud data with cloudnet, aura omi $\mathrm{O}_{2}-\mathrm{O}_{2}$, modis and suomi-npp viirs. Atmos Meas Tech Discuss 2020:1-33. https://doi.org/10.5194/amt-2020-122

Curier RL, Kranenburg R, Segers AJS, Timmermans RMA, Schaap $\mathrm{M}$ (2014) Synergistic use of omi $\mathrm{NO}_{2}$ tropospheric columns and lotos-euros to evaluate the $\mathrm{NO}_{\mathrm{x}}$ emission trends across europe. Remote Sens Environ 149:58-69. https://doi.org/10.1016/j.rse.20 14.03.032

De Foy B, Lu Z, Streets DG (2016) Satellite $\mathrm{NO}_{2}$ retrievals suggest China has exceeded its $\mathrm{NO}_{\mathrm{x}}$ reduction goals from the twelfth fiveyear plan. Sci Rep 6:35912. https://doi.org/10.1038/srep35912

Ding J, Miyazaki K, van der A RJ, Mijling B, Kurokawa J-I, Cho S, Janssens-Maenhout G, Zhang Q, Liu F, Levelt PF (2017) Intercomparison of $\mathrm{NO}_{\mathrm{x}}$ emission inventories over East Asia. Atmos Chem Phys 17(16):10125-10141. https://doi.org/10.5194/acp-17$10125-2017$

Ding J, van der A RJ, Eskes H, Mijling B, Stavrakou T, van Geffen J, Veefkind $\mathrm{P}(2020)$ Chinese $\mathrm{NO}_{\mathrm{x}}$ emission reductions and rebound as a result of the COVID-19 crisis quantified through inversion of tropomi $\mathrm{NO}_{2}$ observations. Geophys Res Lett 47(19):e2020GL089912. https://doi.org/10.1029/2020GL089912

Duncan BN, Lamsal LN, Thompson AM, Yoshida Y, Lu Z, Streets DG, Hurwitz MM, Pickering KE (2016) A space-based, highresolution view of notable changes in urban $\mathrm{NO}_{\mathrm{x}}$ pollution around the world (2005-2014). J Geophys Res Atmos 121(2):976-996. https://doi.org/10.1002/2015JD024121

EEA (2019) Air quality in Europe - eea (european environment agency) 2019 report. Tech. Rep., 10/2019 
Euro (2007) Regulation (ec) no 715/2007 of the european parliament and of the council of 20 june 2007 on type approval of motor vehicles with respect to emissions from light passenger and commercial vehicles (euro 5 and euro 6 ) and on access to vehicle repair and maintenance information 29.6.2007. Tech Rep., Official Journal of the European Union L 171/1., https://eur-lex.europa.eu/ eli/reg/2007/715/oj

Fan C, Li Y, Guang J, Li Z, Elnashar A, Allam M, de Leeuw G (2020) The impact of the control measures during the COVID-19 outbreak on air pollution in China. Remote Sens 12(10):1613. https://doi.org/10.3390/rs12101613

Fioletov V, McLinden CA, Griffin D, Theys N, Loyola DG, Hedelt P, Krotkov NA, Li C (2020) Anthropogenic and volcanic point source $\mathrm{SO}_{2}$ emissions derived from tropomi on board sentinel5 precursor: first results. Atmos Chem Phys 20(9):5591-5607. https://doi.org/10.5194/acp-20-5591-2020

Fishman J, Bowman KW, Burrows JP, Richter A, Chance KV, Edwards DP, Martin RV, Morris GA, Pierce RB, Ziemke JR, Al-Saadi JA, Creilson JK, Schaack TK, Thompson AM (2008) Remote sensing of tropospheric pollution from space. Bull Am Met Soc 89(6):805-822. https://doi.org/10.1175/2008BAMS25 26.1

Georgoulias AK, Boersma KF, van Vliet J, Zhang X, van der A RJ, Zanis $\mathrm{P}$, de Laat $\mathrm{J}$ (2020) Detection of $\mathrm{NO}_{2}$ pollution plumes from individual ships with the tropomi/s5p satellite sensor. Environ Res Lett 15(12):124037. https://doi.org/10.1088/1748-9326/abc445

Georgoulias AK, Stammes P, Boersma KF, Eskes H (2019) Trends and trend reversal detection in 2 decades of tropospheric $\mathrm{NO}_{2}$ satellite observations. Atmos Chem Phys 19(9):6269-6294. https://doi.org/10.5194/acp-19-6269-2019

Goldberg DL, Anenberg S, Mohegh A, Lu Z, Streets DG (2020a) Tropomi $\mathrm{NO}_{2}$ in the United States: a detailed look at the annual averages, weekly cycles, effects of temperature, and correlation with pm2.5. https://doi.org/10.1002/essoar.10503422.1

Goldberg DL, Anenberg SC, Griffin D, Mclinden CA, Lu Z, Streets DG (2020b) Disentangling the impact of the COVID-19 lockdowns on urban $\mathrm{NO}_{2}$ from natural variability. Geophys Res Lett 47(17):e2020GL089269. https://doi.org/10.1029/2020GL089269

Gu D, Wang Y, Smeltzer C, Boersma KF (2014) Anthropogenic emissions of $\mathrm{NO}_{\mathrm{x}}$ over China: reconciling the difference of inverse modeling results using gome- 2 and omi measurements. J Geophys Res Atmos 119(12):7732-7740. https://doi.org/10.1002/2014JD0 21644

Harley RA, Marr LC, Lehner JK, Giddings SN (2005) Changes in motor vehicle emissions on diurnal to decadal time scales and effects on atmospheric composition. Environ Sci Technol 39(14):5356-5362. https://doi.org/10.1021/es048172+

Hayn M, Beirle S, Hamprecht FA, Platt U, Menze BH, Wagner T (2009) Analysing spatio-temporal patterns of the global $\mathrm{NO}_{2}$ distribution retrieved from gome satellite observations using a generalized additive model. Atmos Chem Phys 9(17):6459-6477. https://doi.org/10.5194/acp-9-6459-2009

Hendrick F, Müller J-F, Clémer K, Wang P, De Mazière M, Fayt C, Gielen C, Hermans C, Ma JZ, Pinardi G, Stavrakou T, Vlemmix T, Van Roozendael M (2014) Four years of ground-based max-doas observations of hono and $\mathrm{NO}_{2}$ in the Beijing area. Atmos Chem Phys 14(2):765-781. https://doi.org/10.5194/acp-14-765-2014

Hilboll A, Richter A, Burrows JP (2013) Long-term changes of tropospheric $\mathrm{NO}_{2}$ over megacities derived from multiple satellite instruments. Atmos Chem Phys 13:4145-4169. https://doi.org/10.5194/ acp-13-4145-2013

Hilboll A, Richter A, Burrows JP (2017) $\mathrm{NO}_{2}$ pollution over India observed from space-the impact of rapid economic growth, and a recent decline. ACPD 2017:1-18. https://doi.org/10.5194/acp2017-101
Huang G, Sun K (2020) Non-negligible impacts of clean air regulations on the reduction of tropospheric $\mathrm{NO}_{2}$ over East China during the COVID-19 pandemic observed by omi and tropomi. Sci Total Environ 745:141023. https://doi.org/10.1016/j. scitotenv.2020.141023

Huber DE, Steiner AL, Kort EA (2020) Daily cropland soil $\mathrm{NO}_{\mathrm{x}}$ emissions identified by tropomi and smap. GRL 47(22):e2020GL089949. https://doi.org/10.1029/2020GL089949

Irie H, Boersma KF, Kanaya Y, Takashima H, Pan X, Wang ZF (2012) Quantitative bias estimates for tropospheric $\mathrm{no}_{2}$ columns retrieved from sciamachy, omi, and gome-2 using a common standard for East Asia. Atmos Meas Tech 5(10):2403-2411. https://doi.org/10.5194/amt-5-2403-2012

Ketzel M, Wåhlin P, Berkowicz R, Palmgren F (2003) Particle and trace gas emission factors under urban driving conditions in copenhagen based on street and roof-level observations. Atmos Environ 37(20):2735-2749. https://doi.org/10.1016/S1352-2310(03)0024 5-0

Kleipool Q, Ludewig A, Babić L, Bartstra R, Braak R, Dierssen W, Dewitte P-J, Kenter P, Landzaat R, Leloux J, Loots E, Meijering P, van der Plas E, Rozemeijer N, Schepers D, Schiavini D, Smeets J, Vacanti G, Vonk F, Veefkind P (2018) Pre-launch calibration results of the tropomi payload on-board the sentinel-5 precursor satellite. Atmos Meas Tech 11(12):6439-6479. https://doi.org/ 10.5194/amt-11-6439-2018

Konovalov IB, Beekmann M, Richter A, Burrows JP, Hilboll A (2010) Multi-annual changes of $\mathrm{NO}_{\mathrm{x}}$ emissions in megacity regions: nonlinear trend analysis of satellite measurement based estimates. Atmos Chem Phys 10(17):8481-8498. https://doi.org/10.5194/ acp-10-8481-2010

Koukouli M-E, Skoulidou I, Karavias A, Parcharidis I, Balis D, Manders A, Segers A, Eskes H, Geffen J (2021) Sudden changes in nitrogen dioxide emissions over Greece due to lockdown after the outbreak of COVID-19. Atmos Chem Phys 21(3):1759-1774. https://doi.org/10.5194/acp-21-1759-2021

Krotkov NA, McLinden CA, Li C, Lamsal LN, Celarier EA, Marchenko SV, Swartz WH, Bucsela EJ, Joiner J, Duncan BN, Boersma KF, Veefkind JP, Levelt PF, Fioletov VE, Dickerson RR, $\mathrm{He} \mathrm{H}, \mathrm{Lu} \mathrm{Z}$, Streets DG (2016) Aura omi observations of regional $\mathrm{SO}_{2}$ and $\mathrm{NO}_{2}$ pollution changes from 2005 to 2015. Atmos Chem Phys 16(7):4605-4629. https://doi.org/10.5194/acp-16-4605-2016

Krotkov NA, Lamsal LN, Celarier EA, Swartz WH, Marchenko SV, Bucsela EJ, Chan KL, Wenig M, Zara M (2017) The version 3 omi $\mathrm{NO}_{2}$ standard product. Atmos Meas Tech 10(9):3133-3149

Lambert JC, Compernolle S, Eichmann KU, de Graaf M, Hubert D, Keppens A, Kleipool Q, Langerock B, Sha MK, Verhoelst T, Wagner T, Ahn C, Argyrouli A, Balis D, Chan KL, De Smedt I, Eskes H, Fj?raa AM, Garane K, Gleason JF, Goutail F, Granville J, Hedelt P, Heue KP, Jaross G, Koukouli ML, Landgraf J, Lutz R, Nanda S, Niemejer S, Pazmi?o A, Pinardi G, Pommereau JP, Richter A, Rozemeijer N, Sneep M, SteinZweers D, Theys N, Tilstra G, Torres O, Valks P, van Geffen J, Vigouroux C, Wang P, Weber M (2020) Quarterly validation report of the copernicus sentinel-5 precursor operational data products \#08: April 2018august 2020., s5p mpc routine operations consolidated validation report series, issue \#08, version 08.01.01, 170 pp. Tech. rep.

Lauri M (2020) China?s air pollution overshoots pre-crisis levels for the first time. Tech. Rep., Centre for Research on Energy and Clean Air. https://energyandcleanair.org/wp/wp-content/uploads/ 2020/05/China-air-pollution-rebound-final.pdf

Levelt PF, Van den Oord GHJ, Dobber MR, Malkki A, Visser H, de Vries J, Stammes P, Lundell J, Saari H (2006) The ozone monitoring instrument. IEEE Trans Geosci Remote Sens 44:10931101 
Liu F, Page A, Strode SA, Yoshida Y, Choi S, Zheng B, Lamsal LN, Li C, Krotkov NA, Eskes H, van der A RJ, Veefkind P, Levelt $\mathrm{PF}$, Hauser OP, Joiner J (2020a) Abrupt decline in tropospheric nitrogen dioxide over China after the outbreak of COVID-19. SciAd 6(28):eabc2992. https://doi.org/10.1126/sciadv.abc2992

Liu F, Zhang Q, Zheng B, Tong D, Yan L, Zheng Y, He K (2016) Recent reduction in $\mathrm{NO}_{\mathrm{x}}$ emissions over China: synthesis of satellite observations and emission inventories. Environ Res Lett 11(11):114002. https://doi.org/10.1088/1748-9326/11/11/114002

Liu Q, Harris JT, Chiu LS, Sun D, Houser PR, Yu M, Duffy DQ, Little MM, Yang C (2020b) Spatiotemporal impacts of COVID-19 on air pollution in california, USA. Sci Total Environ 750:141592. https://doi.org/10.1016/j.scitotenv.2020.141592

Liu S, Valks P, Pinardi G, De Smedt I, Yu H, Beirle S, Richter A (2019) An improved total and tropospheric no 2 column retrieval for gome-2. Atmos Meas Tech 12:1029-1057. https://doi.org/10. 5194/amt-12-1029-2019

Liu S (2019) Total and tropospheric $\mathrm{NO}_{2}$ retrieval for gome-2 and tropomi, dissertation. Technical University of Munich, http:// mediatum.ub.tum.de/?id=1509977

Liu S, Valks P, Pinardi G, Xu J, Argyrouli A, Lutz R, Tilstra LG, Huijnen V, Hendrick F, Roozendael MV (2020) An improved air mass factor calculation for nitrogen dioxide measurements from the global ozone monitoring experiment-2 (gome-2). Atmos Meas Tech 13(2):755-787. https://doi.org/10.5194/amt-13-755-2020

Lorente A, Boersma KF, Eskes H, Veefkind JP, van Geffen J, de Zeeuw MB, van der Gon HACD, Beirle S, Krol MC (2019) Quantification of nitrogen oxides emissions from buildup of pollution over paris with tropomi. Sci Rep 9:20033. https://doi.org/10.1038/s41598-019-56428-5

Loyola DG, García SG, Lutz R, Argyrouli A, Romahn F, Spurr RobertJD, Pedergnana M, Doicu A, García VM, Schüssler O (2018) The operational cloud retrieval algorithms from tropomi on board sentinel-5 precursor. Atmos Meas Tech 11(1):409-427. https://doi.org/10.5194/amt-11-409-2018

Lutz R, Loyola DG, Gimeno García S, Romahn F (2016) Ocra radiometric cloud fractions for gome-2 on metop-a/b. Atmos Meas Tech 9:2357-2379. https://doi.org/10.5194/amt-9-2357-2016

Mahato S, Pal S, Ghosh KG (2020) Effect of lockdown amid COVID-19 pandemic on air quality of the megacity Delhi, India. Sci Total Environ 730:139086. https://doi.org/10.1016/j.scitotenv. 2020.139086

Mijling B, van der A RJ, Zhang Q (2013) Regional nitrogen oxides emission trends in east asia observed from space. Atmos Chem Phys 13(23):12003-12012. https://doi.org/10.5194/acp-1312003-2013

Miyazaki K, Eskes H, Sudo K, Boersma KF, Bowman K, Kanaya Y (2017) Decadal changes in global surface $\mathrm{NO}_{\mathrm{x}}$ emissions from multi-constituent satellite data assimilation. Atmos Chem Phys 17(2):807-837. https://doi.org/10.5194/acp-17-807-2017

Munro R, Lang R, Klaes D, Poli G, Retscher C, Lindstrot R, Huckle R, Lacan A, Grzegorski M, Holdak A, Kokhanovsky A, Livschitz J, Eisinger M (2016) The gome-2 instrument on the metop series of satellites: instrument design, calibration, and level 1 data processing - an overview. Atmos Meas Tech 9(3):1279-1301. https://doi.org/10.5194/amt-9-1279-2016

Nakada LYK, Urban RC (2020) COVID-19 pandemic: impacts on the air quality during the partial lockdown in Sao Paulo state, Brazil. Sci Total Environ 730:139087. https://doi.org/10.1016/j.scitotenv. 2020.139087

Penn E, Holloway T (2020) Evaluating current satellite capability to observe diurnal change in nitrogen oxides in preparation for geostationary satellite missions. Environ Res Lett 15(3):034038. https://doi.org/10.1088/1748-9326/ab6b36
Pinardi G, Lambert J-C, Granville J, Yu H, De Smedt I, Granville J, Van Roozendael M, Valks P (2017) Ac saf validation report. Tech. Rep., AF/AC/IASB/VR/NO2, Issue 2/1

Pinardi G, Van Roozendael M, Hendrick F, Theys N, Abuhassan N, Bais A, Boersma F, Cede A, Chong J, Donner S, Drosoglou T, Dzhola A, Eskes H, Frieß U, Granville J, Herman JR, Holla R, Hovila J, Irie H, Kanaya Y, Karagkiozidis D, Kouremeti N, Lambert J-C, Ma J, Peters E, Piters A, Postylyakov O, Richter A, Remmers J, Takashima H, Tiefengraber M, Valks P, Vlemmix T, Wagner T, Wittrock F (2020) Validation of tropospheric no 2 column measurements of gome-2a and omi using max-doas and direct sun network observations. Atmos Meas Tech 13(11):61416174. https://doi.org/10.5194/amt-13-6141-2020

Pinardi G, Van Roozendael M, Lambert J-C, Granville J, Hendrick F, Tack F, Yu H, Cede A, Kanaya Y, Irie I, Goutail F, Pommereau J-P, Pazmino A, Wittrock F, Richter A, Wagner T, Gu M, Remmers J, Friess U, Vlemmix T, Piters A, Hao N, Tiefengraber M, Herman J, Abuhassan N, Bais A, Kouremeti N, Hovila J, Holla R, Chong J, Postylyakov O, Ma J (2014) Gome-2 total and tropospheric $\mathrm{NO}_{2}$ validation based on zenith-sky, direct-sun and multi-axis DOAS network observations. In: Proc. of the 2014 EUMETSAT Meteorological Satellite Conference, Geneva, Swizerland, EUMETSAT

Platt U, Stutz J (2008) Differential optical absorption spectroscopy. Springer, Berlin

Richter A (2009) Nitrogen oxides in the troposphere-what have we learned from satellite measurements? In: EPJ Web of conferences, vol 1. EDP Sciences, pp 149-156

Richter A, Begoin M, Hilboll A, Burrows JP (2011) An improved $\mathrm{NO}_{2}$ retrieval for the GOME-2 satellite instrument. Atmos Meas Tech 4(6):1147-1159. https://doi.org/10.5194/amt-4-1147-2011

Richter A, Burrows JP, Nüß H, Granier C, Niemeier U (2005) Increase in tropospheric nitrogen dioxide over China observed from space. Nature 437(7055):129-132. https://doi.org/10.1038/nature04092

Seinfeld JH, Pandis SN (2016) Atmospheric chemistry and physics: from air pollution to climate change. Wiley, Hoboken

Sharma S, Zhang M, Gao J, Zhang H, Kota SH (2020) Effect of restricted emissions during COVID-19 on air quality in India. Sci Total Environ 728:138878. https://doi.org/10.1016/j.scitotenv. 2020.138878

Silver B, He X, Arnold SR, Spracklen DV (2020) The impact of COVID-19 control measures on air quality in China. Environ Res Lett 15(8):084021. https://doi.org/10.1088/1748-9326/aba3a2

Singh RP, Chauhan A (2020) Impact of lockdown on air quality in india during COVID-19 pandemic. Air Qual Atmos Health 13:921?928. https://doi.org/10.1007/s11869-020-00863-1

Stavrakou T, Müller J-F, Bauwens M, Boersma KF, van Geffen J (2020) Satellite evidence for changes in the $\mathrm{NO}_{2}$ weekly cycle over large cities. Sci Rep 10:10066. https://doi.org/10.1038/s415 98-020-66891-0

Valks P, Loyola DG, Hao N, Hedelt P, Slijkhuis S, Grossi M, Begoin M, Gimeno Garcia S, Lutz R (2020) Algorithm theoretical basis document for GOME-2 total column products of ozone, $\mathrm{NO}_{2}$, bro, $\mathrm{SO}_{2}, \mathrm{H}_{2} \mathrm{O}$, hcho and cloud properties (gdp 4.8 for ac saf oto and nto). Tech. rep., SAF/AC/DLR/ATBD/01, Iss./Rev.: 3/A/2

Valks P, Pinardi G, Richter A, Lambert J-C, Hao N, Loyola DG, van Roozendael M, Emmadi S (2011) Operational total and tropospheric $\mathrm{NO}_{2}$ column retrieval for GOME-2. Atmos Meas Tech 4(7):1491-1514. https://doi.org/10.5194/amt-4-1491-2011

van der A RJ, de Laat ATJ, Ding J, Eskes H (2020) Connecting the dots: $\mathrm{No}_{\mathrm{x}}$ emissions along a West Siberian natural gas pipeline. NCAS 3:16. https://doi.org/10.1038/s41612-020-0119-z

van der A RJ, Mijling B, Ding J, Koukouli ME, Liu F, Li Q, Mao H, Theys N (2017) Cleaning up the air: effectiveness of air quality 
policy for $\mathrm{SO}_{2}$ and $\mathrm{NO}_{\mathrm{x}}$ emissions in China. Atmos Chem Phys 17(3):1775-1789. https://doi.org/10.5194/acp-17-1775-2017

van Geffen J, Boersma KF, Eskes H, Maasakkers JD, Veefkind JP (2020a) Tropomi atbd of the total and tropospheric $\mathrm{NO}_{2}$ data products. Tech. rep., S5P-KNMI-L2-0005-RP issue 1.4.0.

van Geffen J, Boersma KF, Eskes H, Sneep M, Ter Linden M, Zara M, Veefkind JP (2020b) S5p tropomi no 2 slant column retrieval: method, stability, uncertainties and comparisons with omi. Atmos Meas Tech 13(3):1315-1335. https://doi.org/10.5194/amt-13-13 15-2020

Veefkind JP, Aben I, McMullan K, Förster H, De Vries J, Otter G, Claas J, Eskes H, De Haan JF, Kleipool Q, van Weele M, Hasekamp O, Hoogeveen R, Landgraf J, Snel R, Tol P, Ingmann P, Voors R, Kruizinga B, Vink R, Visser H, Levelt PF (2012) Tropomi on the ESA sentinel-5 precursor: a GMES mission for global observations of the atmospheric composition for climate, air quality and ozone layer applications. Remote Sens Environ 120:70-83. https://doi.org/10.1016/j.rse.2011.09.027

Wang Y, Wen Y, Wang Y, Zhang S, Zhang KM, Zheng H, Xing J, Wu Y, Hao J (2020) Four-month changes in air quality during and after the COVID-19 lockdown in six megacities in China. Environ Sci Technol 7(11):802-808. https://doi.org/10.1021/ acs.estlett.0c00605

Wu Y, Zhang S, Hao J, Liu H, Wu X, Hu J, Walsh MP, Wallington TJ, Zhang KM, Stevanovic S (2017) On-road vehicle emissions and their control in China: A review and outlook. Sci Total Environ 574:332-349. https://doi.org/10.1016/j.scitotenv.2016.09.040

Zalakeviciute R, Vasquez R, Bayas D, Buenano A, Mejia D, Zegarra R, Diaz A, Lamb B (2020) Drastic improvements in air quality in Ecuador during the COVID-19 outbreak. Aerosol Air Qual Res 20:1783-1792. https://doi.org/10.4209/aaqr.2020.05.0254

Zhang R, Zhang Y, Lin H, Feng X, Fu T-M, Wang Y (2020) $\mathrm{NO}_{\mathrm{x}}$ emission reduction and recovery during COVID-19 in East China. Atmosphere 11(4):433. https://doi.org/10.3390/atmos11040433

Zhao Y, Zhang K, Xu X, Shen H, Zhu X, Zhang Y, Hu Y, Shen $G$ (2020) Substantial changes in nitrogen dioxide and ozone after excluding meteorological impacts during the COVID-19 outbreak in mainland China. Environ Sci Technol 7:402-408. https://doi.org/10.1021/acs.estlett.0c00304

Zheng B, Geng G, Ciais P, Davis SJ, Martin RV, Meng J, Wu N, Chevallier F, Broquet G, Boersma F, van der A RJ, Lin J, Guan D, Lei Y, He K, Zhang Q (2020a) Satellite-based estimates of decline and rebound in China?s $\mathrm{CO}_{2}$ emissions during COVID-19 pandemic. Sci Adv 6(49):eabd4998. https://doi.org/10.1126/sciadv. abd4998

Zheng B, Zhang Q, Geng G, Shi Q, Lei Y, He K (2020) Changes in China's anthropogenic emissions during the COVID-19 pandemic. Earth Syst Sci Data 2020b:1-20. https://doi.org/10.5194/ essd-2020-355

Zhou Y, Brunner D, Hueglin C, Henne S, Staehelin J (2012) Changes in omi tropospheric $\mathrm{NO}_{2}$ columns over europe from 2004 to 2009 and the influence of meteorological variability. Atmos Environ 46:482-495. https://doi.org/10.1016/j.atmosenv.2011.09.024

Publisher's note Springer Nature remains neutral with regard to jurisdictional claims in published maps and institutional affiliations. 